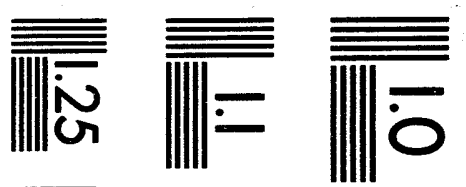

$$
\begin{aligned}
& \sqrt{\bar{I}}
\end{aligned}
$$

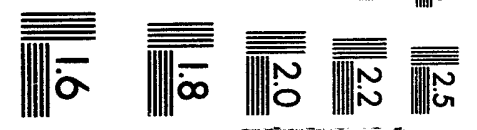



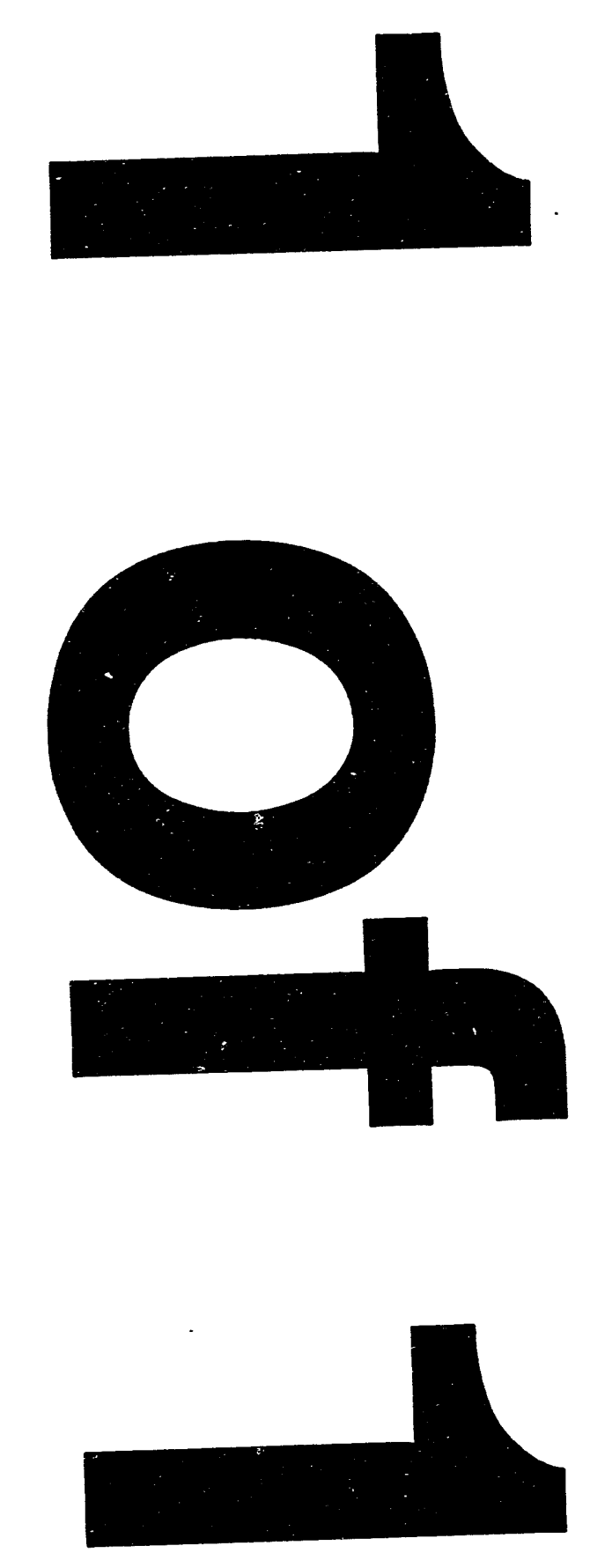
Environmental Restoration Division ORNL Environmental Restoration Program

\title{
Toxicological Benchmarks for Screening Potential Contaminants of Concern for Effects on Terrestrial Plants
}

\author{
G. W. Suter II, \\ M. E. Will, \\ and C. Evans
}

Date Issued-September 1993

OAK RIDGE NATIONAL LABORATORY

Oak Ridge, Tennessee 37831-6285 managed by

MARTIN MARIETTA ENERGY SYSTEMS, INC. for the

U.S. DEPARTMENT OF ENERGY under contract DE-AC05-84OR21400 



\section{CONTENTS}

EXECUTIVE SUMMARY $\ldots \ldots \ldots \ldots \ldots \ldots \ldots \ldots \ldots \ldots \ldots$ ix

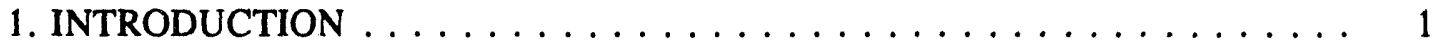

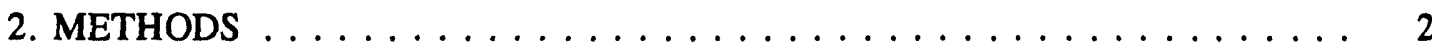

2.1 DATA .......................... 2

2.2 SELECTION OF TYPES AND LEVELS OF EFFECTS . . . . . . . . . 4

2.3 DERIVATION OF BENCHMARKS $\ldots \ldots \ldots \ldots \ldots \ldots$

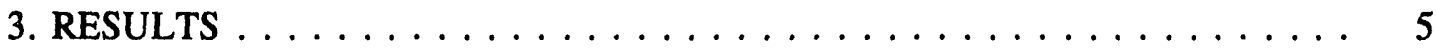

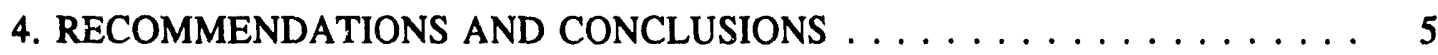

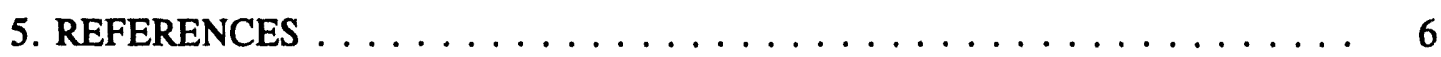




\section{TABLES}

Table 1. Phytotoxicity data used in the derivation of soil benchmarks (NOEC and LOEC concentrations are $\mathrm{mg} / \mathrm{kg}$ of the element.

Duration is measured in days.) $\ldots \ldots \ldots \ldots \ldots \ldots \ldots \ldots$

Table 2. Screening benchmark concentrations for the phytotoxicity of chemicals in soil and soil solution (Letters after concentrations denote values said in secondary sources to represent phytotoxicity thresholds.) . . . 26 


\section{ACRONYMS and ABBREVIATIONS}

DOE United States Department of Energy

EPA United States Environmental Protection Agency

ER-L Effects Range Low

$\mathrm{HCl} \quad$ Hydrochloric Acid

LCT Lowest Concentration Tested

LOEC Lowest Observed Effect Concentration

NOEC No Observed Effect Concentration

PCB Polychlorinated Biphenyl 


\section{ACKNOWLEDGMENTS}

The authors would like to thank the following individuals for their helpful reviews of the document: Richard Bonczek, Jeffery Duncan, Ruth Hull, David Kocher, Bobette Nourse, Dennis Opresko, Mark Stack, and Barbara Walton. The literature review for this report was begun by Melanie Futrell. 


\section{EXECUTIVE SUMMARY}

One of the initial stages in ecological risk assessment for hazardous waste sites is the screening of contaminants to determine which of them are worthy of further consideration as "contaminants of potential concern." This process is termed "contaminant screening." It is performed by comparing measured ambient concentrations of chemicals to benchmark concentrations. Currently, no standard benchmark concentrations exist for assessing contaminants in soil with respect to their toxicity to plants. This report presents a standard method for deriving benchmarks for this purpose (phytotoxicity benchmarks), a set of data concerning effects of chemicals in soil or soil solution on plants, and a set of phytotoxicity benchmarks for 34 chemicals potentially associated with U.S. Department of Energy (DOE) sites. Chemicals that are found in soil at concentrations exceeding both the phytotoxicity benchmark and the background concentration for the soil type should be considered con aminants of potential concern. 


\section{INTRODUCTION}

An important step in ecological risk assessment is screening the chemicals occurring on a site for contaminants of potential concern. Screening may be accomplished by comparing reported concentrations in media to a set of toxicological benchmarks. If a chemical concentration or the reported detection limit exceeds the screening benchmark, more analysis is needed to determine the hazards posed by that chemical (i.e., it is a contaminant of potential concern). If, however, the chemical concentration or its detection limit falls below the proposed benchmark, the chemical may be ignored during further study unless public concern or ancillary evidence suggest that it should be retained.

The purpose of this report is to present plant toxicity data and discuss their utility as benchmarks for determining the hazard to terrestrial plants caused by contaminants in soil. Benchmarks are provided for soils and solutions.

Tests of the toxicity of chemicals in the rooting medium of plants are conducted using a variety of rooting media. We have divided them into three categories: soil, solution, and other. Tests conducted in natural soils (even when brought into the laboratory, dried, sieved, fertilized, etc.) are assumed to be representative of the exposure of plants to contaminants measured in field soils. Tests conducted in nutrient solutions are assumed to be representative of exposures of plants to contaminants measured in soil solutions (e.g., from lysimeter samples or possibly from aqueous extracts of soil) or in very shallow groundwater (e.g., plants in the vicinity of seeps and springs). The other category includes media that are neither soils nor solutions, such as silica sand and vermiculite. Data from such studies are not clearly related to any contaminant measurements in ambient media. However, they are included in the review for purposes of comparison.

Soil benchmarks are based on data provided only by toxicity studies in either the field or pots. The reported toxic concentrations are not all equivalent to concentrations reported from field sites. Most of the soil concentrations of metals reported from waste sites are from extractions with hydrochloric acid $(\mathrm{HCl})$ or other mineral acids which are intended to provide total concentrations. Similarly, concentrations of organic contaminants in waste site soils are total concentrations derived from rigorous solvent extractions. In some cases, toxicity tests report concentrations extracted from contaminated soils, but various extractants are used that may not yield total concentrations. More commonly, the concentrations reported are nominal concentrations of a soluble form (i.e., a highly bioavailable form) of the chemical added to soil.

Solution benchmarks include data from toxicity tests conducted using whole plants rooted in aquecus nutrient solutions. Tests are commonly conducted in this manner because plants are assumed to be exposed to contaminants in the solution phase of soil and the presence of soil in test systems reduces the experimenter's degree of control over exposure. Groundwater samples from waste sites are typically acidified before analysis to obtain total concentrations, but some samples are filtered before acidification.

In general, the concentrations in prefiltered samples are likely to be more comparable to the concentrations reported from solution toxicity tests and should be used if available. 
These benchmarks are to serve for contaminant screening only. Plant toxicity may be affected by many variables: $\mathrm{pH}$, Eh, cation exchange capacity, moisture content, interactions with other elements, and organic matter and clay content of the soil. In addition, different species react to different contaminants with varying degrees of toxicity, and the sensitivity of plants may be affected by its physiological condition. No systematic tests that thoroughly examine the effects of these variables on plant toxicity are known to these authors. An assessor must realize that these soil characteristics play a large part in plant toxicity and incorporate these site-specific considerations in the evaluation of the potential hazards of a chemical. If chemical concentrations reported in field soils that support vigorous and diverse plant communities exceed one or more of the benchmarks presented in this report or if a benchmark exceeds background soil concentrations, it is generally safe to assume that the benchmark is a poor measure of risk at that site.

\section{METHODS}

\subsection{DATA}

References on the toxicity of selected chemicals to terrestrial plants were obtained from searches of bibliographic data bases (BIOSIS, POL TOX I), a numeric data base (PHYTOTOX), review articles, and conventional literature searching. The target was reports of toxicity tests of individual chemicals in laboratory, greenhouse, or field settings.

Data presented in this report were derived mainly from primary sources. Secondary sources were used if the primary source cited in the secondary source was unavailable, if only a little data for a particular chemical were available, and if secondary sources suggested that a benchmark derived from limited primary source material was too high. The general criteria for inclusion of a study in the data set used to derive phytotoxicity benchmarks were:

1. Methodology was clearly stated (especially concentrations of applied chemicals) and followed in the experiment.

2. Results were quantified as measures of plant growth or yield (e.g., weight, height). Measures of metabolic activity or tissuc chemical concentration were used if measures of growth or yield were not available for a particular chemical of interest.

3. Results were presented in numeric form or graphical presentations of data were clearly interpretable.

4. An unambiguous reduction existed in the measured parameter within the range of applied concentrations of the chemical of interest.

The data selected using these criteria were assigned to the following categories for analysis:

1. Chemical-The effects of individual chemicals of interest were analyzed. In the case of 
metals, the metal itself is listed in the "Chemical" field, with the salt listed in the "Form" field. For organics, the specific compound is listed in the "Chemical" field, except in the case of polychlorinated biphenyl (PCB) for which the specific Aroclor mixture is listed in the "Form" field.

2. Growth Medium-Methodologies were divided into three general groupings of growth media:

a. Solution: this category includes experiments in which the roots of plants were submerged in solutions of variable composition containing the chemical of interest. In most studies, plant growth nutrients were added. Solution $\mathrm{pH}$ was noted when given.

b. Soil: this category includes soils derived from field soil profiles, regardless of subsequent preparation and experimental location. Soil $\mathrm{pH}$ and organic matter content were noted when given. Percentage organic carbon was converted to the more frequently cited measure of percentage organic matter, by the equation (Nelson and Sommers, 1982):

\%organic carbon $\times 2=$ \%organic matter

c. Other: this group is made up of alternative growth media such as pure quartz or silica sand, vermiculite, and peat moss. Medium $\mathrm{pH}$ was noted when given.

3. Plant Species-The analysis was limited to terrestrial vascular plants, mainly domestic cultivars. Plant growth stages were seed germination and early growth, seedling, or seedling to maturity (e.g., grains and vegetables).

4. Exposure duration-The durations of exposure of the test plants to chemicals of interest ranged from 2 to 279 days, with trees generally being exposed longer than plants with shorter life spans.

5. NOEC-The no observed effect concentration (NOEC) is defined here as the highest applied concentration of the chemical of interest which gave a reduction of $20 \%$ or less in a measured response.

6. LOEC-The lowest observed effect concentration (LOEC) is defined here as the lowest applied concentration of the chemical of interest which gave a greater than $20 \%$ reduction in a measured response. In some cases, the LOEC for the test was the lowest concentration tested (LCT) or the only concentration tested, as of when the $\mathrm{EC}_{\mathbf{s}_{0}}$ was reported.

7. Response parameter-The majority of the responses were oven-dry weights of whole plants or their parts. Others included root length, plant height, relative growth rate, grain yield, seeds per plant, percent seed germination, and fresh and air-dry weights. Responses other than these growth and yield parameters were included only if growth or yield parameters were unavailable for a chemical. Transpiration rate, $\mathrm{CO}_{2}$ uptake, and chlorophyll content of needles were recorded for methyl mercury; chlorophyll content of needles for mercury also was recorded. 


\subsection{SELECTION OF TYPES AND LEVELS OF EFFECTS}

Growth and yield parameters were used for two reasons. First, they are the most common class of response parameters reported from phytotoxicity studies thereby using those parameters allowed for derivation of reasonably consistent benchmarks for a large number of contaminants. Second, growth and yield are ecologically significant responses both in terms of the plant populations and the ability of the biota to support higher trophic levels.

Twenty percent reduction in growth or yield was used as the threshold for significant effects to be consistent with other screening benchmarks for ecological risk assessment and with current regulatory practice (Suter et al., 1992). In brief, most regulatory criteria are based on concentrations that cause effects that are statistically significantly different from controls, which on average correspond to greater than $20 \%$ effects. In addition, regulatory actions may be based on comparisons of biological parameters measured on contaminated sites to those from reference sites. Differences between sites generally must be greater than $20 \%$ to be reliably detected in such studies. Therefore, the $20 \%$ effects level is treated as a conservative approximation of the threshold for regulatory concern.

\subsection{DERIVATION OF BENCHMARKS}

Because of the diversity of soils, plant species, chemical forms, and test procedures, it is not possible to estimate concentrations that would constitute a threshold for toxic effects on the plant communities at particular sites from published toxicity data. This situation is analogous to the problem of deriving benchmarks for sediments. In this report, the method used for deriving soil benchmarks is based on the National Oceanographic and Atmospheric Administration's method for deriving the Effects Range Low (ER-L) (Long and Morgan, 1990) which has been recommended as a sediment screening benchmark by U.S. Environmental Protection Agency (EPA) Region IV. The ER-L is the tenth percentile of the distribution of various toxic effects thresholds for various organisms in sediments.

This approach can be justified by assuming that the toxicity of a chemical in soil is a random variate, that the toxicity of contaminated soil at a particular site is drawn from the same distribution, and that the assessor should be $90 \%$ certain of protecting plants growing in the site soil. Any bias in the data set would mitigate against that assumption. In this implementation of the approach, the bias most likely to be significant is the use of soluble salts of metals in the toxicity tests which are likely to be more toxic than the mixture of forms encountered in field soils. That bias would result in conservative benchmark values. Other possible sources of bias include the use of predominately domestic plant species that may not be representative of plant species in general, use of predominately agricultural soils which may not be representative of soils in general, and the laboratory test conditions which may not be representative of field conditions. The direction and magnitude of these potential biases is unknown.

The phytotoxicity benchmarks were derived by rank ordering the LOEC values and then picking a number that approximated the tenth percentile. As with the ER-Ls, statistical fitting was not used because there was seldom sufficient data and because these benchmarks are to be used as screening values and do not require the consistency and precision of regalatory criteria. 
If there were 10 or fewer values for a chemical, the lowest LOEC was used. If there were more than 10 values, the tenth percentile LOEC value was used. If the tenth percentile fell between LOEC values, a value was chosen by interpolation. In all cases, benchmark values were rounded to one significant figure.

Another possible source of benchmark values is values recommended in published reviews of the phytotoxicity literature. When primary literature is unavailable for a particular contaminant, concentrations identified in reviews as thresholds for phytotoxicity are used as benchmarks. In addition, when fewer than three LOEC values were found for a chemical in soil or solution, and a toxicity threshold from a review is lower than the lowest LOEC, the toxicity threshold is used as the benchmark for that chemical.

Any scheme for deriving a set of standard ecotoxicological benchmarks is based on assumptions that may be questioned by readers. The procedure used here is one that is consistent with current regulatory practice and contains a minimum of assumptions or factors. Those who care to make other assumptions or to add safety factors may make use of the data presented here to calculate their own benchmarks.

\section{RESULTS}

Results of the literature review are summarized in Table 1. Proposed screening benchmarks for phytotoxic effects of contaminants in soils and solutions are presented in Table 2.

\section{RECOMMENDATIONS AND CONCLUSIONS}

The values presented in Table 2 are intended for contaminant screening in the hazard identification (problem formulation) phase of ecological risk assessments. Chemicals with soil concentrations that exceed both the phytotoxicity benchmark for soil and the background soil concentration for the soil type, and which may be derived from waste disposal, are contaminants of potential concern. Background soil concentrations have been derived for the Oak Ridge Reservation and should be generated for other Comprehensive Environmental Response, Compensation and Liability Act (CERCLA) sites as well. Similarly, soil solution or shallow groundwater concentrations that exceed both the phytotoxicity benchmark for solutions and the background water concentration for the aquifer, which may be derived from waste disposal, and to which plant roots may be exposed are contaminants of potential concern.

For baseline ecological risk assessments, and other assessments that may lead to regulatory actions, assessors should consult the primary sources of toxicity data and then determine the applicability of the data to their specific site. In addition, assessments should not blindly rely on laboratory toxicity data. Where phytotoxicity is suspected, phytotoxicity tests should be performed with the contaminated soil. In addition, the site should be surveyed for signs of phytotoxicity such as inexplicable bare areas, low plant diversity, low plant vigor, or symptoms of toxic injury. 


\section{REFERENCES}

Adema D. M. M. and L. Henzen. 1989. "A comparison of plant toxicities of some industrial chemicals in soil culture and soilless culture." Ecotoxicol. Environ. Saf. 18:219-29.

Aery, N. C. and S. Sarkar. 1991. "Studies on the effect of heavy metal stress on growth parameters of soybean." J. Environ. Biol. 12(1):15-24.

Aldrich, D. G., A. P. Vanselow, and G. R. Bradford. 1951. "Lithium toxicity in citrus." Soil Sci. 71:291-95.

Bowen, H. J. M. 1979. Environmental Chemistry of the Elements. Academic Press, London.

Breeze, V. G. 1973. "Land reclamation and river pollution problems in the Croal Valley caused by waste from chromate manufacture." J. Appl. Ecol. 10:513-525.

Burke, D. G., K. Watkins, and B. J. Scott. 1990. "Manganese toxicity effects on visible symptoms, yield, manganese levels, and organic acid levels in tolerant and sensitive wheat cultivars." Crop Sci. 30:275-80.

Burton, K. W., E. Morgan, and A. Roig. 1984. "The influence of heavy metals upon the growth of sitka-spruce in South Wales forests." Plant Soil. 78:271-82.

Carlson, C. L., D. C. Adriano, and P. M. Dixon. 1991. "Effects of soil-applied selenium on the growth and selenium content of forage species." J. Environ. Qual. 20:363-68.

Carlson, R. W. and F. A. Bazzaz. 1977. "Growth reduction in American Sycamore (Plantanus occidentalis L.) caused by $\mathrm{Pb}-\mathrm{Cd}$ interaction." Environ. Pollut. 12:243-53.

Carlson, R. W. and G. L. Rolfe. 1979. "Growth of rye grass and fescue as affected by leadcadmium-fertilizer interaction." J. Environ. Qual. 8(3):348-352.

Carroll, M. D., and J. F. Loneragan. 1968. "Response of plant species to concentrations of zinc in solution." Aust. J. Agric. Res. 19:859-68.

Chapman, H. D. (ed.). 1966. Diagnostic Criteria for Plants and Soils. Univ. of California, Div. Agric. Sci. Cited in Bowen, H.J.M. 1979. Environmental Chemistry of the Elements. Academic Press, London.

Chaudhry, F. M., A. Wallace, and R. T. Mueller. 1977. "Barium toxicity in plants." Commun. Soil Sci. Plant Anal. 8(9):795-97.

Cunningham, L. M. 1977. Physiological and biochemical aspects of cadmium in soybean: The effects of induced $\mathrm{Cd}$ toxicity on the uptake and translocation of $\mathrm{Zn}, \mathrm{Fe}, \mathrm{Mg}, \mathrm{Ca}$ and $\mathrm{K}$. Proc. Annual Conf. on Trace Substances in the Environment, pp. 133-45. 
Deuel, L. E. and A. R. Swoboda. 1972. "Arsenic toxicity to cotton and soybeans." J. Environ. Qual. 1:317-20.

Dixon, R. K. 1988. "Response of ectomycorrhizal Quercus rubra to soil cadmium, nickel and lead." Soil Biol. Biochem. 20(4):555-59.

Dvorak, A. J., B. G. Lewis, et al. 1978. Impacts of coal-fired power plants on fish, wildlife, and their habitats. U.S. Fish and Wildlife Service Report No. FWS/OBS-78/29, Ann Arbor, Mich.

U.S. Environmental Protection Agency (EPA). 1975. Preliminary Investigation of Effects of Boron, Indium, Nickel, Selenium, Tin, Vanadium, and Their Compounds, Vol. VI, Vanadium. U.S. EPA Report No. EPA-560/2-75-005f. Cited in EPA. 1980. A Screening Procedure for the Impacts of Air Pollution Sources on Plants, Soils, and Animals. EPA 450/2-81-078. Wast ington, D.C.

Gall, O. E. and R. M. Barnette. 1940. "Toxic limits of replaceable zinc to corn and cowpeas grown of three Florida soils." J. Am. Soc. Agron. 32:23-32.

Görransson, A. and T. D. Eldhuset. 1991. "Effects of aluminum on growth and nutrient uptake of small Picea abies and Pinus sylvestris plants." Trees. 5:136-42.

Gupta, D. B. and S. Mukherji. 1977. "Effects of toxic concentrations of copper on growth and metabolism of rice seedlings." Z. Pflanzenphysiol. Bd. 82:95-106.

Haghiri, F. 1973. "Cadmium uptake by plants." J. Environ. Qual. 2(1):93-95.

Hara, T., Y. Sonoda, and I. Iwai. 1976. "Growth response of cabbage plants to transition elements under water culture conditions." Soil Sci. Plant Nutr. 22(3):307-315.

Hassett, J. J., J. E. Miller, and D. E. Koeppe. 1976. "Interaction of lead and cadmium on maize root growth and uptake of lead and cadmium by roots." Environ. Pollut. 11:297-302.

Hooper, M. C. 1937. "An investigation of the effect of lead on plants." Ann. Appl. Biol. 24:690-695.

Hutton, E. M., W. T. Willams, and C. S. Andrew. 1978. "Differential Tolerance to manganese in introduced and bred lines of Macroptilium atropurpureum." Aust. J. Agric. Res. 29:67-79.

John, M. K., H. H. Chuah, and C. J. VanLaerhoven. 1977. "Boron response and toxicity as affected by soil properties and rates of boron." Soil Sci. 124:34-39.

Keisling, T. C., D. A. Lauer, M. E. Walker, and R. J. Henning. 1977. "Visual, tissue, and soil factors associated with $\mathrm{Zn}$ toxicity of peanuts." Agronomy J. 69(5):765-69.

Keltjens, W. G. 1990. "Effects of aluminum on growth and nutrient status of Douglas-fir seedlings grown in culture solution." Tree Physiol. 6:165-75. 
Khalid, B. Y. and J. Tinsley. 1980. "Some effects of nickel toxicity on rye grass." Plant Soil. 55:139-44.

Khan, D. H. and B. Frankland. 1983. "Effects of cadmium and lead on radish plants with particular reference to movement of metals through soil profile and plant." Plant Soil. 70:335-345.

Khan, D. H. and B. Frankland. 1984. "Cellulolytic activity and root biomass production in some metal-contaminated soils." Environ. Pollut. 33:63-74.

Kitagishi, K. and I. Yamane (eds.). 1981. Heavy Metal Pollution of Soils of Japan. Japan Sci. Soc. Press, Japan. Cited in A. Kabata-Pendias and H. Pendias (eds.). 1984. Trace Elements in Soils and Plants. CRC Press, Boca Raton, Florida.

Kloke, A. 1979. Content of arsenic, cadmium, chromium, fluorine, lead, mercury, and nickel in plants grown on contaminated soil. Paper presented at United Nations-ECE Symp. Effects of Air-borne Pollution on Vegetation. Warsaw. Cited in A. Kabata-Pendias and H. Pendias (eds.). 1984. Trace Elements in Soils and Plants. CRC Press, Inc. Boca Raton, Florida.

Kovalskiy, V. V. 1974. "Geochemical environment, health and diseases. In: Trace Substances in Environmental Health, Vol. 8, D. D. Hemphill (ed.) Univ. Missouri, Columbia, MO., p. 137.

Lamoreaux, R. J. and W. R. Chaney. 1977. "Growth and water movement in silver maple seedlings affected by cadmium." J. Environ. Qual. 6(2):201-04.

Langheinrich, U., R. Tischner, and D. L. Godbold. 1992. "Influence of a high Mn supply on Norway spruce [Picea abies (L.) Karst.] seedlings in relation to the nitrogen source." Tree Physiol. 10:259-71.

Lata, K. and B. Veer. 1990. "Phytotoxicity of Zn amended soil to Spinacia and Coriandrum." Acta Bot. Indica. 18:194-198.

Le Bot, J., E. A. Kirkby, ard M. L. van Beusichem. 1990. "Manganese toxicity in tomato plants: Effects on cation uptake and distribution." J. Plant Nutr. 13(5):513-25.

Lee, R. C. and N. R. Page. 1967. "Soil factors influencing the growth of cotton following peach orchards." Agronomy J. 59:237-40.

Lewis, J. C. and W. L. Powers. 1941. "Antagonistic action of chlorides on the toxicity of iodides to corn." Plant Physiol. 393-98.

Lin, Z. and D. L. Myhre. 1991. "Differential response of citrus rootstocks to aluminum levels in nutrient solutions: I. Plant growth." J. Plant Nutr. 14(11):1223-38.

Linzon, S. N. 1978. Phytotoxically excessive levels for contaminants in soil and vegetation. Report of Ministry of the Environment. Ontario, Canada. Cited in A. Kabata-Pendias and H. 
Pendias (eds.). 1984. Trace Elements in Soils and Plants. CRC Press, Boca Raton, Florida.

Long, R. E. and L. G. Morgan. 1990. The potential for biological effects of sediment-sorbed contaminants tested in the national status and trends program. NOAA Technical Memorandum NOS OMA 52.

Macleod, L. B. and L. P. Jackson. 1967. "Aluminum tolerance of two barley varieties in nutrient solution, peat, and soil culture." Agronomy J. 59:359-63.

Martin, A. L. 1937. "A comparison of the effects of tellurium and selenium on plants and animals." Am. J. Bot. 24:198-203.

Martin, A. L. 1937. "Toxicity of selenium to plants and animals." Am. J. Bot. 23:471-483.

McLean, F. T. and B. E. Gilbert. 1927. "The relative aluminum tolerance of crop plants." Soil Sci. 24:163-74.

Miles, L. J. and G. R. Parker. 1979. "Heavy metal interaction for Andropogon scoparius and Rudbeckia hirta grown on soil from urban and rural sites with heavy metals additions." $J$. Environ. Qual. 8(4):443-49.

Miller, J. E., J. J. Hassett, and D. E. Koeppe. 1977. "Interactions of lead and cadmium on metal uptake and growth of corn plants." J. Environ. Qual. 6(1):18-20.

Muramoto, S., H. Nishizaki, and I. Aoyama. 1990. "The critical levels and the maximum metal uptake for wheat and rice plants when applying metal oxides to soil." J. Environ. Sci. Health, Part B 25(2):273-80.

Nelson, D. W., and L. E. Sommers. 1982. "Total carbon, organic carbon, and organic matter." In: Methods of Soil Analysis, Part 2. p. 574. ASA/SSSA. Madison, WI.

Newton, H. P. and S. J. Toth. 1952. "Response of crop plants to I and Br." Soil Sci. 73:127-34.

Overcash, R. M., J. B. Weber, and M. L. Miles. 1982. Behavior of organic priority pollutants in the terrestrial system: Di-n-butyl phthalate ester, toluene, and 2,4 dinitrophenol. UNCWRRI-82-171. Water Resources Research Institute, Univ. North Carolina.

Page, A. L., F. T. Bingham, and C. Nelson. 1972. "Cadmium absorption and growth of various plant species as influenced by solution cadmium concentration." J. Environ. Qual. 1(3):288-91.

Patel, P. M., and A. Wallace, and R. T. Mueller. 1976. "Some effects of copper, cobalt, cadmium, zinc, nickel, and chromium on growth and mineral element concentration in chrysanthemum." J. Am. Soc. Hortic. Sci. 101(5):553-556.

Romney, E. M. and J. D. Childress. 1965. "Effects of beryllium in plants and soil." Soil Sci. 100(2):210-17. 
Romney, E. M., J. D. Childress, and G. V. Alexander. 1962. "Beryllium and the growth of bush beans." Science. 185:786-87.

Sadana, U. S. and B. Singh. 1987a. "Yield and uptake of cadmium, lead and zinc by wheat grown in soil polluted with heavy metals." J. Plant Sci. Res. 3:11-17.

Sadana, U. S. and B. Singh. 1987b. "Effect of zinc application of yield and cadmium content of spinach (Spinacea oleracea L.) grown in a cadmium-polluted soil." Ann. Biol. 3:59-60.

Scharrer, K. 1955. Biochemie der Spurenelemente. Parey, Berlin. Cited in Bowen, H.J.M. 1979. Environmental Chemistry of the Elements. Academic Press, London.

Schlegel, H., D. L. Godbold, and A. Huttermann. 1987. "Whole plant aspects of heavy metal induced changes in $\mathrm{CO} 2$ uptake and water relations of spruce (Picea abies) seedlings." Physiol. Plantarum. 69:265-70.

Schroeder, H. A., J. J. Balassa, and I. H. Tipton. 1964. "Abnormal trace elements in man: Tin." J. Chronic Dis. 17:483-502.

Singh, B. B. 1971. "Effect of vanadium on the growth, yield and chemical composition of maize (Zea mays L.)." Plant Soil. 34:209-12.

Singh, A., N. K. Goyal, and A. P. Gupta. 1991. "Effect of cadmium and farm yard manure on the concentration and uptake of zinc by wheat in texturally different soils." Crop Res. 4(2):199-205.

Smith, G. S. and J. H. Watkinson. 1984. "Selenium toxicity in perennial ryegrass and white clover." New Phytol. 97:557-64.

Spencer, E. L. 1937. "Frenching of tobacco and thallium toxicity." Am. J. Bot. 24:16-24.

Stiborova, M., R. Hromadkova, and S. Leblova. 1986. "Effect of ions of heavy metals on the photosynthetic characteristics of maize (Zea mays L.)." Biologia. 41(12):1221-28.

Stiles, W. 1958. Encyclopaedia of Plant Physiology, Vol. 4. Springer-Verlag, N.Y. Cited in Bowen, H.J.M. 1979. Environmental Chemistry of the Elements. Academic Press, London.

Strek, J. H. and J. B Weber. 1980. Absorption and translocation of polychlorinated biphenyls (PCBs) by weeds. Proc. South. Weed Sci. Soc. 33:226-232.

Strek, J. H. and J. B. Weber. 1982. "Adsorption and reduction in bioactivity of polychlorinated biphenyl (Aroclor 1254) to redroot pigweed by soil organic matter and montmorillonite clay." Soil Sci. Soc. Am. J. 46:318-22.

Struckmeyer, B. E., L. A. Peterson, and F. Hsi-Mer Tai. 1969. "Effects of copper on the composition and anatomy of tobacco." Agronomy J. 61:932-936. 
Suter, G. W., II. 1992. Approach and strategy for performing ecological risk assessments for the Department of Energy Oak Ridge Field Office Environmental Restoration Program. ES/ER/TM-33. Oak Ridge National Laboratory, Environmental Science Division.

Traynor, M. F. and B. D. Knezek. 1973. Effects of nickel and cadmium contaminated soils on nutrient composition of corn plants. Proc. Annual Conf. on Trace Substances in the Environment. 7:82-87.

Trelease, S. F. and H. M. Trelease. 1938. "Selenium as a stimulating and possibly essential element for indicator plants." Am. J. of Bot. 25:372-79.

Turner, M. A. 1973. "Effect of cadmium treatment on cadmium and zinc uptake by selected vegetable species." J. Environ. Qual. 2(1):118-19.

Turner, M. A. and R. H. Rust. 1971. Effects of chromium on growth and mineral nutrition of soybeans. Soil Sci. Soc. Am. Proc. 35:755-58.

Wallace, A. 1979. "Excess trace metal effects on calcium distribution in plants." Commun. Soil Sci. Plant Anal. 10:473-79.

Wallace, A. and E. M. Romney. 1977. "Aluminum toxicity in plants grown in solution culture." Commun. Soil Sci. Plant Anal. 8(9):791-94.

Wallace, A., G. V. Alexander, and F. M. Chaudhry. 19/7a. "Phytotoxicity of cobalt, vanadium, titanium, silver, and chromium." Commun. Soil Sci. Plant Anal. 8(9):751-56.

Wallace, A., G. V. Alexander, and F. M. Chaudhry. 1977b. "Phytotoxicity and some interactions of the essential trace metals iron, manganese, molybdenum, zinc, copper, and boron." Commun. Soil Sci. Plant Anal. 8(9):741-50.

Wallace, A., R. M. Romney, J. W. Cha, S. M. Soufi, and F. M. Chaudhry. 1977c. "Lithium toxicity in plants." Commun. Soil Sci. Plant Anal. 8(9):773-80.

Wallace, A., R. M. Romney, J. W. Cha, S. M. Soufi, and F. M. Chaudhry. 1977d. "Nickel phytotoxicity in relationship to soil $\mathrm{pH}$ manipulation and chelating agents." Commun. Soil Sci. Plant Anal. 8(9):757-64.

Weber, J. B. and E. Mrozek, Jr. 1979. "Polychlorinated biphenyls: Phytotoxicity, absorption and translocation by plants, and inactivation by activated carbon." Bull. Environ. Contam. Toxicol. 23:412-17.

Wheeler, D. M. and J. M. Follet. 1991. "Effect of aluminum on onions, asparagus and squash." J. Plant Nutr. 14(9):897-912.

White, M. C., R. L. Chaney, and A. M. Decker. 1979. "Differential cultivar tolerance in soybean to phytotoxic levels of soil $\mathrm{Zn}$. II. Range of $\mathrm{Zn}$ additions and the uptake and translocation of Zn, Mn, Fe, and P." Agronomy J. 71:Jan-Feb. 
Wickliff, C., and H. J. Evans. 1980. "Effect of cadmium on the root and nodule ultrastructure of Alnus rubra." Environ. Pollut., Ser. A. 21:287-306.

Wickliff, C., H. J. Evans, K. R. Carter, and S. A. Russell. 1980. "Cadmium effects on the nitrogen fixation system of red alder." J. Environ. Qual. 9(2):180-183.

Wong, M. H. and A. D. Bradshaw. 1982. "A comparison of the toxicity of heavy metals, using root elongation of rye grass, Lolium perenne." New Phytol. 92:255-61.

Wong, M. H. and W. M. Lau. 1985. "Root growth of Cynodon and Eleusine indica collected from motorways at different concentrations of lead." Environ. Res. 36:257-67. 
Table 1. Phytotoxicity data used in the derivation of soil benchmarks (NOEC and LOEC concentrations are $\mathrm{mg} / \mathrm{kg}$ of the element.

Duration is measured in days.)

\begin{tabular}{|c|c|c|c|c|c|c|c|c|c|c|}
\hline CHEMICAL & GROWTH MEDIUM & FORM & SPECIES & DURATION & NOEC & LOEC & NOTES & GROWTH PARAMETER & $\mathrm{pH}$ & REFERENCE \\
\hline Aluminum & Soil & AICB & Barky & 24 & 6 & 12 & & Dry wet. roodshoot & 4 & Maclood and Jactson. 1967. \\
\hline Aluminum & Soil & ACCB & Barky & 24 & 6 & 12 & & Dry wgt. ptent & 6 & Mackood and Juckson. 1967. \\
\hline Alumimum & Soil & $\mathrm{AlCB}$ & Barky & 24 & 6 & 12 & & Dry wat. root/sbook & 4 & Maclood and Jachoon. 1967. \\
\hline Aluminum & Solution & $\mathrm{Al} 2(\mathrm{SO} 4) 3$ & Asparagus & & 0.05 & 0.13 & & Dry wgt. roolshoot & 4.7 & Whocker and Folket. 1991. \\
\hline Aluminum & Solution & $\mathrm{Al2}(\mathrm{SO} 4) 3$ & Rioe & 13 & 0.27 & 2.7 & & Dry wgt. rood/shood & & Wallace und Romney. 1977. \\
\hline Ahrmimum & Solution & $\mathrm{ACl3}+\mathrm{N}(\mathrm{NO} 3) 3$ & Sprose & 21 & 5.4 & 8.1 & & Rel. gwth rate root & 3.8 & Goreneson and Eldhusect. 1991. \\
\hline Alumimum & Solution & $\mathrm{A12}(\mathrm{SO} 4) 3$ & Soybean & 13 & 0.27 & 2.7 & & Dry wgt. roodshood & & Wallace and Rormey. 1977. \\
\hline Aluminum & Solution & $\mathrm{A} 2(\mathrm{SO}-4) 3$ & Lettuos & 56 & 0.9 & 1.8 & & Air dry wat. plant & 4.3 & McLean and Gilber. 1927. \\
\hline Aluminum & Solution & $\mathrm{Al} 2(\mathrm{SO} 4) 3$ & Lemon & 60 & 4.8 & 8.3 & & Freah wgt; rook kength & 4 & Lin and Myhre. 1991. \\
\hline Aluminum & Solution & $\mathrm{Al} 2(\mathrm{SO} 4) 2$ & Turnip & $n$ & 3.6 & 7.2 & & Air dry wgl. shoot & 4.3 & McLcan and Gilbert. 1927. \\
\hline Alumimm & Solution & $\mathrm{Al}(\mathrm{SO} 4)^{3}$ & Rye & x & & 3.5 & LCT & Air dry wght rook & 4.5 & MeLcen and Giber. 1927. \\
\hline Numinum & Solution & $\mathrm{An}(\mathrm{SO} 4) 3$ & Lettuce & 56 & 1.8 & 2.7 & & Air dry wgt. plent & 4.3 & McLean and Gilbert. 1927. \\
\hline Numimum & Solution & $\mathrm{An}(\mathrm{SO} 4) 3$ & Orange & 60 & 4.8 & 8.3 & & Frext- wgt; rook length & 4 & Lin and Mybre. 1991. \\
\hline Aluenimum & Solution & $\mathrm{Al} 2\left(\mathrm{SO}_{4}\right) 3$ & Boet & $\pi$ & & 1.8 & LCT & Air dy wat. plene & 4.3 & Mclean and Gilber. 1927. \\
\hline Aluminum & Solution & $\mathrm{Al}(\mathrm{SO} 4)_{3}$ & Barky & $\pi$ & & 1.8 & LCT & Air dry waz. roodsbod & 4.3 & Mclean and Gibert. 1927. \\
\hline Aluminum & Solution & $\mathrm{AJCl3}+\mathrm{Al}(\mathrm{NO} 3)_{3}$ & Pine & 21 & 161.9 & 269.8 & & Rel. guth rate shoox & 3.8 & Goransecon and Eldhweet. 1991. \\
\hline Aluminum & Solution & $\mathrm{AN}(\mathrm{SO} 4)^{3}$ & Rediah & $n$ & 1.8 & 3.6 & & Air dry wzt. rootshoot & 4.3 & Melean and Gilbert. 1927. \\
\hline Alumimum & Solution & $\mathrm{ACB}$ & Barky & 30 & 4 & 6 & & Dry wgt. rootshood & 4.3 & Macbood and Jackson. 1967. \\
\hline Alumimum & Solution & $\mathrm{A} 2\left(\mathrm{SO}_{4}\right) 3$ & Rye & 63 & & 1.8 & LCT & Air dy wgt. rook & 4.3 & Mclean and Gilber. 1927. \\
\hline Aluminum & Solution & $\mathrm{ACl3}$ & Dougles fir & 279 & 16 & 32 & & Dry wgt. roodgth. & 3.5 & Keitjens. 1990. \\
\hline Alumimm & Solution & $\mathrm{Al} 2(\mathrm{SO} 4) 3$ & Letture & 42 & 0.54 & 1.08 & & Air dry wgt. shoot & 4.3 & McLean and Gilber. 1927. \\
\hline Aluminum & Solution & $\mathrm{Al} 2\left(\mathrm{SO}_{4}\right) 3$ & Boet & 126 & & 1.8 & LCT & Air dy wgt. pleanx & 4.3 & McLcan and Gilbert. 1927. \\
\hline Alumimum & Solution & $\mathrm{Al2}(\mathrm{SO}) 3$ & Citrumelo & 60 & 4.8 & 8.3 & & Fresh wgt. plane & 4 & Lin and Mytre. 1991. \\
\hline Alumimum & Solution & $\mathrm{A} 2(\mathrm{SO} 4) 3$ & Carrot & 126 & & 3.6 & LCT & Air dry wath. planer & 4.3 & Mclean and Gilbert. 1927. \\
\hline Alumimum & Solution & $\mathrm{A}(2,(\mathrm{SO} 4) 3$ & Carrot & 126 & & 3.6 & LCT & Air dry wigt. plent & 4.3 & Melean and Gilbert. 1927. \\
\hline
\end{tabular}


Table 1. (continued)

\begin{tabular}{|c|c|c|c|c|c|c|c|c|c|c|}
\hline CHEMICAL & GROWTH MEDIUM & FORM & SPECIES & DURATION & NOEC & LOEC & NOTES & GROWTH PARAMETER & $\mathrm{pH}$ & REFERENCE \\
\hline Aluminam & Solvetion & $\mathrm{A} 12(\mathrm{SO} 4) 3$ & Douglase fir & 279 & 4 & 8 & & Dry wat. roct & 7.5 & Keltjecses. 1990. \\
\hline Aluminum & Solution & $\mathrm{A12}(\mathrm{SO}-4) 3$ & Oat & 63 & 3.6 & 7.2 & & Air dry wgh. root/sboox & 4.3 & McLean and Gilber. 1927. \\
\hline Aluminum & Sohtution & $\mathrm{An}(\mathrm{SO} 4)^{3} 3$ & Squesth & 26 & 0.13 & 0.27 & & Dry wat. rook & 4.7 & Whocker and Follet. 1991. \\
\hline Aluminum & Solvtion & $\mathrm{Al2}(\mathrm{SO} 4) 3$ & Boet & 126 & & 1.8 & LCT & Air dry wat planx & 0 & McLean and Gibert. 1927. \\
\hline Aluminum & Solution & $\mathrm{KA}\left(\mathrm{SO}_{4}\right) 2$ & Rye grase & 14 & & 0.63 & LCT & Lgth longest root & 7 & Wong and Brodahbw. 1982 \\
\hline Aluminam & Solution & $\mathrm{AD}(\mathrm{SO} 4) 3$ & Citrnege & 60 & 0.11 & 2.7 & & Rool kngeth & 4 & Lin and Mybre. 1991. \\
\hline Aluminum & Solution & $\mathrm{Alz}(\mathrm{SO} 4) 3$ & Carrox & 126 & & 3.6 & LCT & Air dy wgt. plent & 4.3 & MeLcen end Gilbert. 1927. \\
\hline Aluminum & Solution & Al2(SO4)3 & Orange & 60 & 8.3 & 24.4 & & Freath wot; rook lengeth & 4 & Lin and Mybre. 1991. \\
\hline Alumimum & Solution & AL2(SO4)3 & Cabbage & 9 & & 7.2 & LCT & Air dry wgt. plene & 4.3 & Melean and Gilber. 1927. \\
\hline Ahemimm & Solution & $\mathrm{Al} 2(\mathrm{SO} 4) 3$ & Berky & 30 & 8 & 10 & & Dry wgt, rooushood & 4.3 & Macbood Jacloon. 1967. \\
\hline Aluminum & Solution & $\mathrm{AL2}(\mathrm{SO} 4)_{3}$ & Onioa & 31 & & 0.05 & LCT & Dry wigt. rooushook & 4.7 & Whocker and Follet. 1991. \\
\hline Ancimony & Surface soil & & & & & $s$ & & Phytoxoxic & & Klobe. 1979. \\
\hline Arsecaic & Black elay & $\mathrm{A} s 203$ & Sogtean & 42 & & 22.4 & LCT & Dny wgt. shoot & & Devel and Swoboda. 1972. \\
\hline Arsenic & Bleck clay & $\mathbf{A} 203$ & Cotion & 42 & 67.2 & 89.6 & & Dry wgt. ahood & & Devel and Swoboda. 1972. \\
\hline Anenic & Fine senty loom & $\mathrm{As}_{203}$ & Cotton & 42 & & 11.2 & LCT & Dry wgt. shood & & Devel and Swoboda. 1972. \\
\hline Aneanic & Fine sunty boem & As203 & Soybean & 42 & & 11.2 & LCT & Dry wigh. sbood & & Deucl and Swoboda. 1972. \\
\hline Arsenic & Solution & & & & & 0.02 & LCT & Ptyrotoxic & & Scharner. 1955. \\
\hline Berium & Loem & $\mathrm{Ba}(\mathrm{NO3}) 2$ & Barky & 14 & & 500 & LCT & Dry wgt. pleax & & Chaudhry, et al. 1977 . \\
\hline Barium & Loam & $\operatorname{Ba}(\mathrm{NO}) 2$ & Bush beans & 14 & 100 & 2000 & & Dry wgt. pland & & Chaudhry, et al. 1977. \\
\hline Barium & Solution & & & & & 500 & LCT & Phyrotoxic & & Chapman 1966. \\
\hline Berylliun & Solution & BeC12 & Bartley & 20 & & 2 & LCT & Dry wath. plant & 5.3 & Romney and Childress. 1965. \\
\hline Beryllium & Solution & $\mathrm{BeCl2}$ & Alfalfia & 54 & 2 & 4 & & Dry wat- plene & 5.3 & Romney and Childress. 1965 \\
\hline Beryllium & Solution & & Bean & 48 & & 0.5 & LCT & Dry wegt. plant & 5.3 & Ramerey, et al. 1962. \\
\hline Benylitium & Solution & $\mathrm{BOCl2}$ & Pea & 24 & & 2 & LCT & Dry wgt. plens & 5.3 & Rommey and Childreas. 1965. \\
\hline Beryllium & Solution & $\mathrm{BeCl}$ & Letwoe & 28 & & 2 & LCT & Dry wat. pleme & 5.3 & Romney and Childress. 1965. \\
\hline
\end{tabular}


Table 1. (continued)

\begin{tabular}{|c|c|c|c|c|c|c|c|c|c|c|}
\hline CHEMICAL & GROWTH MEDIUM & FORM & SPECIES & DURATION & NOEC & LOEC & NOTES & GROWTH PARAMETER & $\mathrm{pH}$ & REFERENCE \\
\hline Beryllium & Surface soil & & & & & 10 & & Phytoloxic & & Klabe. 1979. \\
\hline Biamuth & Solution & & & & & 27 & & Phyrowaxic & & Scharrer. 1955. \\
\hline Borcen & Muck & H3BO3 & Com & 28 & 10 & so & & Dry wet. shook & 4.5 & Jotn, et al. 1977 . \\
\hline Boron & Silt loom & H3BO3 & Conn & 28 & 10 & so & & Dry wgt. shood & 5.7 & John, et al. 1977 . \\
\hline Boron & Sill hoom & H3BO3 & Com & 28 & & 0.5 & LCT & Dry wget. ahoor & 5.7 & John, a el. 1977 . \\
\hline Boron & Solution & & & & & 1 & LCT & Phytolocic & & Bowen 1979. \\
\hline Bonos & Solunion & H3BO3 & Buanh beans & 16 & 1.08 & 5.4 & & Dry wat. rookleaves & & Walleos, et sl. $1977 \mathrm{~b}$. \\
\hline Bromine & Solution & & & & & 15 & LCT & Phytoloxic & & Chaprean. 1966. \\
\hline Bromine & Surfinoe soil & & & & & 10 & & Ptyytotoxic & & Kloke. 1979. \\
\hline Cosmium & Allturial soil & Cdo & Rise & 105 & 30 & 100 & & Dry argt. root/stem & 5.95 & Muramolo, et al. 1990. \\
\hline Commium & Alluvial soil & CaO & Wheat & 161 & 10 & 30 & & Yield grain & 5.95 & Murumoto, et si. 1990. \\
\hline Codmium & Brown carth soil & $\operatorname{cac} 12+\operatorname{CsO}(1: 1)$ & Redish & 42 & & so & LCT & Dry wat. rook & 4.6 & Khan end Franklend. 1984. \\
\hline Catmium & Brown earth soil & $\operatorname{cdc} 2$ & Redish & 42 & & 10 & LCT & Dry wgt. roodshook & 5.4 & Khen and Frankland. 1983. \\
\hline Codminum & Brown carth soil & $\operatorname{coc} 2$ & Oat & 42 & & 10 & LCT & Dry wge. sox & 5.4 & Khom and Frankland. 1984. \\
\hline Codminm & Brown carth soil & Cdo & Wheat & 42 & & 100 & LCT & Dry wat. rook & 4.6 & Khan end Frembiturd. 1984. \\
\hline Codmingm & Brown farth woil & CdO & Redish & 42 & & 100 & LCT & Dry wgt. roolshoor & 5.4 & Khen and Frankidend. 1983. \\
\hline Cadmium & Brown certh soil & Cacr & Wheat & 42 & & so & LCT & Dry wet. rook & 4.6 & Khan and Franldend. 1984. \\
\hline Codmiurm & Humic sand & $\mathrm{CaCl} 2$ & Tomato & 14 & & 171 & ECso $\pi$ & Fresh wat. shoor & 5.1 & Aderine and Henven. 1989. \\
\hline Codminum & Humic sand & $\operatorname{CaCl} 2$ & Lettuse & 14 & & 136 & ECSO\% & Freah wgt. shool & 5.1 & Ademe and Henben. 1989. \\
\hline Cosmium & Humic sand & $\mathrm{CaCl} 2$ & Oat & 14 & & 97 & ECSO\% & Freah wgt, shoot & 5.1 & Adema and Hencen. 1989. \\
\hline Commium & Loum & $\operatorname{CdCR}$ & Ont & 14 & & 159 & ECSOS & Dry wat kaves & 7.5 & Ademe and Henzen. 1989. \\
\hline Codminm & Loem & $\mathrm{CaCl}$ & Tomato & 14 & & 16 & ECSO\% & Froesh wgt. shook & 7.5 & Ademan and Hemeen. 1989. \\
\hline Cominium & Loem & Cac12 & Letwore & 14 & & 33 & ECSO\% & Freah wget. ahoor & 7.5 & Ademe and Henzeen. 1989. \\
\hline Cadmium & Loamy sand & & Com & 31 & & 2.5 & LCT & Dry wigh. aboox & 6 & Miller, et al. 1977 . \\
\hline Cestrinim & Loany send & $\operatorname{CdCL}$ & Com & $s$ & 15 & 25 & & Rool kngeth & 6.5 & Hesocet, at al. 1976. \\
\hline
\end{tabular}


Table 1. (continued)

\begin{tabular}{|c|c|c|c|c|c|c|c|c|c|c|}
\hline CHEMICAL & GROWTH MEDIUM & FORM & SPECIES & DURATION & NOEC & LOEC & NOTES & GROWTH PARAMETER & $\mathrm{pH}$ & REFERENCE \\
\hline Codminem & Loamy sand & & Spinach & no & 2 & 4 & & Dry wat. plane & 8.3 & Sedene and Sineh 19876. \\
\hline Commium & Loanny and & & Wheat & & & 10 & LCT & Yeld grain & 8.4 & Sadmen and Sineh 1987. \\
\hline Cadmium & Send & $\mathrm{CaCl} 2$ & Bluestem & 84 & & 10 & LCT & Dry wet. roolsbook & 7.8 & Mileo and Parker. 1979. \\
\hline Cadmium & Sand & $\operatorname{CaCl} 2$ & Com & 35 & & 28 & LCT & Dry wat. Flanx & $s$ & Trmynor and Knezek. 1973 \\
\hline Codmium & Sand culture & $\operatorname{cdct}$ & Red alder & $n$ & 0.031 & 0.062 & & Dry wet. roodstem & & Wickliff and Evans. 1980. \\
\hline Codmium & Sandy loam & $\mathrm{CdC12}$ & Rod oak & 112 & 20 & so & & Dry wat. plemir & 6 & Dixca. 1988. \\
\hline Codmium & Sandy + ciny loums & $\operatorname{cac} 2$ & Wheat & 45 & 10 & 20 & & Yield grain/unsw & 8.4 & Singh, et al. 1991. \\
\hline Codmium & Silica sand & $\mathrm{CaC12}$ & Rod alder & $n$ & & 0.061 & LCT & Dry wgt. stem/keaves & & Wickliff, et al. 1980. \\
\hline Codmium & Silica send & $\mathrm{CaC12}$ & Silver Maple & 56 & & 5 & LCT & Dry wht. rood leaf/stem & & Lemorecuix and Chaney. 1977. \\
\hline Codmium & Silty clay lo & $\operatorname{CdC12}$ & Letruace & 37 & & 2.5 & LCT & Dry wgt. plent & 6.7 & Heghiri. 1973. \\
\hline Cadmium & Silty cley loam & $\mathrm{CdCl} 2$ & Soybean & 35 & 5 & 10 & & Dry wgt. shood & 6.7 & Haghiri. 1973. \\
\hline Codmium & Silty clay loem & $\operatorname{CaCl} 2$ & Sycamore & 90 & & 5 & LCT & Leaf biomess & & Carbon and Bazzer. 1977. \\
\hline Cadmium & Silty clay loem & Cace & Radish & 26 & & 2.5 & LCT & Dry wgt. rook & 6.7 & Hegtiri. 1975. \\
\hline Cadmium & Silty cley toem & cace & Wheat & 35 & 2.5 & 5 & & Dry wgr. shook & 6.7 & Heghiri. 1973. \\
\hline Codminum & Soil & $\operatorname{cdc12}$ & Soytean & & 5 & 10 & & Soods per plant & & Aery and Sabar. 1991. \\
\hline Cedmium & Soil + and $(1: 1)$ & $\operatorname{CaC} 12$ & Spruax & 100 & 1 & 2 & & Dyy wgt. rooctshoor & 3.3 & Burton, et al. 1984. \\
\hline Codmium & Solution & $\operatorname{coc} 2$ & Suiss chand & 35 & 0.1 & 1 & & Dry wgt. shoot & 6.3 & Tumer. 1973. \\
\hline Codmium & Solution & CdSO 4 & Tomato & 21 & & 1 & LCT & Dry wegt. plent & & Page, et al. 1972. \\
\hline Codmium & Solution & CdSO4 & Chrysenmbemam & 21 & & 0.112 & LCT & Dry wgt. roodstem & & Patel, et al. 1976. \\
\hline Cadmium & Solution & $\mathrm{CdC12}$ & Rye & 10 & so & 100 & & Dry wigh. shood & 5.9 & Carbon and Rolie. 1979. \\
\hline Cadmium & Solution & $\mathrm{CdSO} 4$ & Bean & 21 & & 0.1 & LCT & Dry wgt. plent & & Page, et al. 1972. \\
\hline Codmium & Solution & $\mathrm{CdSO} 4$ & Bean & 15 & 0.06 & 6.1 & & Dry wgt. roodkeaves & 5 & Wallace. 1979. \\
\hline Cadmium & Solution & $\mathrm{CdCD}$ & Tomato & 14 & & 3 & ECSO\% & Fresh wght shoot & & Ademe and Henzen. 1989. \\
\hline Codmium & Solution & CdsO4 & Pepper & 21 & & 1 & LCT & Dry wigt. plant & & Page, et al. 1972. \\
\hline Cadmium & Solution & Caso 4 & Turnip & 21 & & 0.1 & LCT & Dry wet. plant & & Page, a al. 1972. \\
\hline
\end{tabular}


Table 1. (continued)

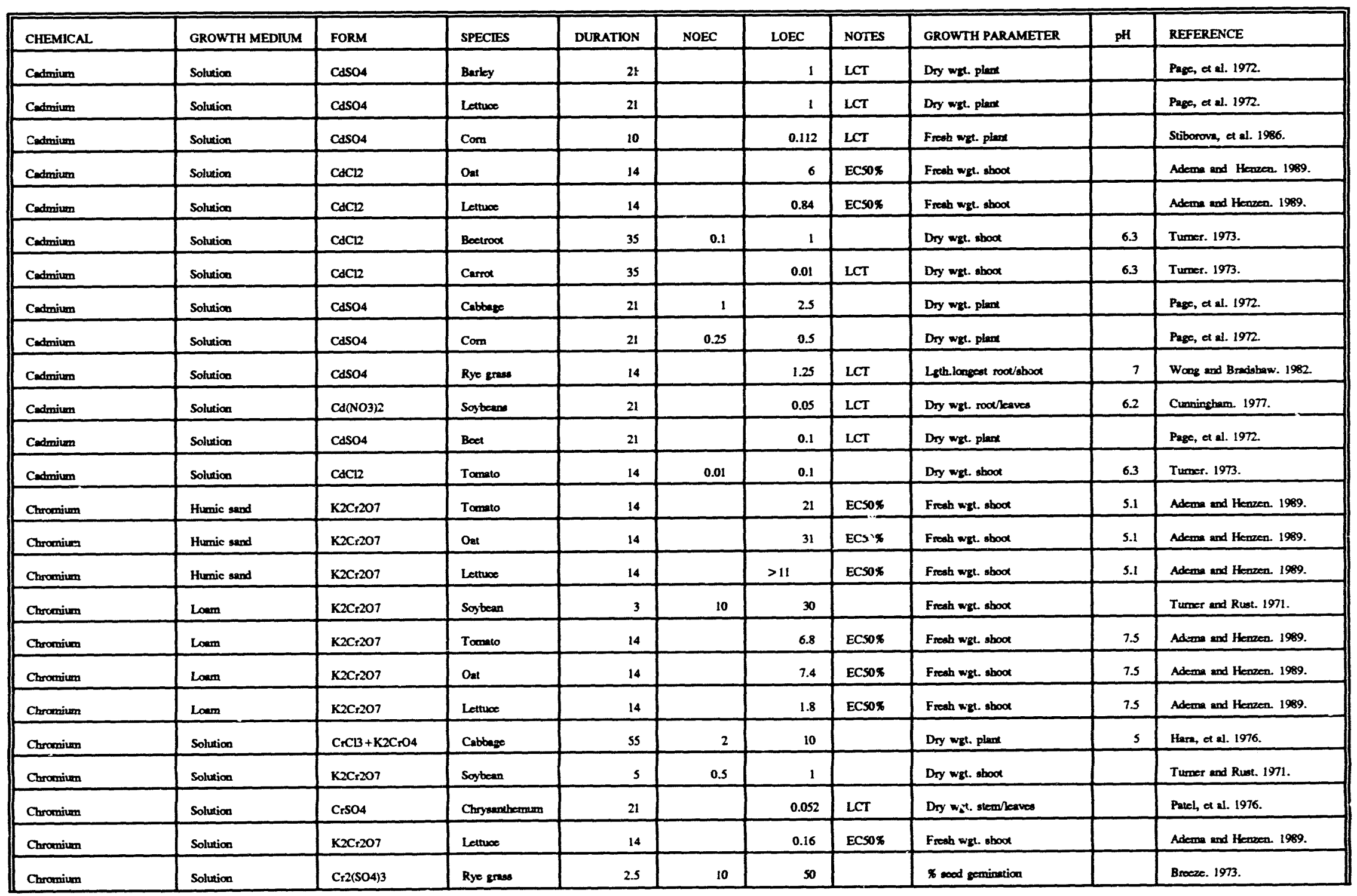


Table 1. (continued)

\begin{tabular}{|c|c|c|c|c|c|c|c|c|c|c|}
\hline CHEMKCAL & GROWTH MEDIUM & FORM & SPECIES & DURATION & NOEE & LOEC & NOTES & GROWTH PARAMETER & pH & REFERENCE \\
\hline Chromiun & Solution & $\mathrm{K} 2 \mathrm{Cr}_{2} 207$ & One & 14 & & 1.4 & ECsox $\pi$ & Frooh wat. abook & & Adeone end Heween 1989. \\
\hline Chromium & Solution & Cr2K207 & Rye grome & 2.5 & 10 & 50 & & 5 eood perminetion & & Broese. 1973. \\
\hline Chromivem & Solution & $\mathrm{K} 2 \mathrm{Cr} 207$ & Rye zrenes & 14 & & 2.5 & LCT & Leth lonoper rood & 7 & Wore und Bradehww. 1982. \\
\hline Chromitrm & Solution & $\mathrm{K} 2 \mathrm{Cr} 2 \mathrm{OP}$ & Bunt beave & 11 & & 0.27 & LCT & Dry wa. beaf & & Wallece, of el. 1977 . \\
\hline Chromiven & Solution & $\mathrm{K} 2 \mathrm{Cr} 2 \mathrm{O} 7$ & Tomato & 14 & & 0.29 & ECSOX & Freab art. ahoox & & Adean and Heren. 1989. \\
\hline Catalt & Solveion & $\mathrm{CaSO4}$ & Bumh beane & 21 & & 0.06 & LCT & Dry wat. kaveo & & Walleses of al. $1977 \mathrm{~h}$. \\
\hline Cobalt & Surfico soil & & & & & 25 & & Ptaytodaric & & Limen. 1978. \\
\hline Cobant & Solution & $\cos 04$ & Chryenesteman & 21 & & 0.059 & LCT & Dry wat. root & & Patel, ef ell. 1976. \\
\hline Copper & Loent & $\mathrm{CuSO}$ & Buenh beave & 17 & 100 & 200 & & Dry wa. leaves & & Wallace, at al. 19776. \\
\hline Copper & Send & $\mathrm{CuSO4}$ & Blueden & 84 & & 100 & LCT & Dry wat. roodshook & 7.8 & Miles and Parker. 1979. \\
\hline Copper & Sand & CusO4 & Blueatem & 84 & & 100 & LCT & Dry wat. roou/shood & 4.8 & Miles and Parker. 1979. \\
\hline Coppe: & Soil & & Clover & 130 & & $\$$ & LCT & Propodoxic & & Dvorak, a al. 1978. \\
\hline Copper & Solution & CusO4 & Rice & 4 & 2.53 & 25.3 & & Roor kength & & Gupen and Multerji. 1977. \\
\hline Copper & Solution & CusO4 & Tobecoso & 21 & 0.16 & 0.32 & & Dry negt. roodshood & & Structumeyer, ex al. 1969. \\
\hline Copper & Solution & CusO4 & Rye gras: & 14 & & 0.031 & LCT & Leth. lonseat rood & 7 & Wons and Bradebaw. 1982 \\
\hline Copper & Solution & $\mathrm{CuSO}_{4}$ & Com & 10 & & 0.064 & LCT & Freah wat. pleme & & Stiborove, at al. 1986. \\
\hline Copper & Surfice soil & & & & & $\infty$ & & Payrodoxic & & Kovalektiy. 1974. \\
\hline Copper & Solution & CusOA & Chryeunhenaum & 21 & & 0.064 & LCT & Dry wat. rook & & Pakel, a al. 1976 \\
\hline Dinitropheani, 2,4 & Clay & & Fencove & 21 & 30 & 40 & & Freeth wat. abood & 4.75 & Overcensh, at al. 1982. \\
\hline Dinitrophenol, 2,4 & Cany & & Com & 21 & 20 & 40 & & Freash wat. shook & 4.75 & Overcough, et al. 1982. \\
\hline Dinitrophenol, 24 & Clay & & Sogbeen & 21 & & & LCT & Freah wagt. ahoor & 4.75 & Overcenelh, et at. 1982. \\
\hline Dinitrophenol, 2,4 & Sandy loam & & Sogtcen & & 30 & - & & x sood permination & 4 & Overcenth, ef el. 1962. \\
\hline Dinitropherool, 24 & Sandy loan & & Foscove & 21 & $\infty$ & 80 & & Froech wart. ahoor & 6 & Overcansh, at al. 1962. \\
\hline Dinitrophenol, 24 & Senty toom & & Con & & 60 & 80 & & S sood germination & 4 & Overcanth, at al. 1982 \\
\hline Dinitrophesol, 2,4 & Sendy loam & & Fonare & 21 & 30 & $\infty$ & & Freab wize. ahood & 4 & Overomen, $\alpha$ al. 1982. \\
\hline
\end{tabular}


Table 1. (continued)

\begin{tabular}{|c|c|c|c|c|c|c|c|c|c|c|}
\hline CHEMICAL & GROWTH MEDIUM & FORM & SPECIES & DURATION & NOEC & LOEC & NOTES & GROWTH PARAMETER & $\mathbf{p H}$ & REFERENCE \\
\hline Dinitrophenol, 2,4 & Sendy loum & & Com & $2+$ & 20 & 40 & & Freoh wat. abook & 6 & Overcenth, at al. 1982. \\
\hline Dinitroptenol, 2,4 & Sendy loam & & Soybeans & 21 & 20 & 40 & & Froech wat. shook & 4 & Overcenth, et al. 1982. \\
\hline Dinitrophenol, 2,4 & Sandy loum & & Com & 21 & & 20 & LCT & Freah wgt. shoot & 4 & Overenth, at al. 1982. \\
\hline Dinitrophenol, 2,4 & Sandy loam & & Soybeans & 21 & & 20 & LCT & Freath wgl. abook & 6 & Overcant, at al. 1982. \\
\hline Di-n-buryl phthalate & Clay & & Fenare & 21 & 200 & 2000 & & Frecth wat. shook & 4.75 & Overcenth, et al. 1982. \\
\hline Di-n-butyl phahalake & Cley & & Corm & 21 & & 200 & LCT & Freah wat. ahook & 4.75 & Overceseth, at al. 1982 \\
\hline Di-n-buxyl phethalele & Sendy loam & & $\cos$ & 21 & & 200 & LCT & Freah wght abook & 5.75 & Overcesesh, at al. 1982. \\
\hline Di-n-butyl ptathalace & Senty loam & & Foscue & 21 & 200 & 2000 & & Freah wht. shoor & 5.75 & Overcanth, et al. 1982. \\
\hline Di-n-buxyl phethalate & Sandy loam & & Soybean & 21 & & 200 & LCT & Freoth wgt. aboor & 5.75 & Overcash, of al. 1982. \\
\hline Di-n-butyl phathaleve & Senty loom & & Soybean & & & 200 & LCT & $x$ eood germination & 4 & Overcanes, et al. 1982. \\
\hline Di-n-butyl phehalece & Sandy loam & & Com & 21 & & 200 & LCT & Freah wgt. :000/abeot & 4 & Overcash, et al. 1982. \\
\hline Fluorine & Surface soil & & & & & 200 & & Pintodoxic & & Klobe. 1979. \\
\hline Fluorine & Solution & & & & & 5 & LCT & Phytoloxic & & Scharrer. 1955. \\
\hline lodine & Loam & $\mathbf{K I}$ & Tomato & 95 & 0.45 & 4.5 & & Dry wgt. sbook & 6.75 & Newton and Toh. 1952 \\
\hline Iodine & Send & $\mathbf{K I}$ & Tomato & 95 & 0.45 & 4.5 & & Dry wgt. thook & 6.75 & Nenton and Tohh. 1952. \\
\hline Iodine & Silt loam & $\mathbf{K I}$ & Tomato & 95 & 0.45 & 4.5 & & Dry. wel. shood & 6.75 & Newton and Toh. 1952. \\
\hline Iodine & Silt loom & $\mathbf{K I}$ & Tomato & 95 & 0.45 & 4.5 & & Dry wgt. shook & 6.75 & Neatcon and Toch. 1952. \\
\hline Jodine & Solution & $\mathbf{k} \mathbf{I}$ & Tomato & 60 & 0.5 & $s$ & & Dry wat. shood & & Newron and Toh. 1952. \\
\hline Iodine & Solution & $\mathbf{K I}$ & Com & $\infty$ & 0.1 & 0.5 & & Dry wgt. sbook & 5.8 & Lewis and Powers. 1941. \\
\hline Iron & Solution & FosO4 & Bueh beams & 15 & 11.6 & 29 & & Dry wgh. rooricaf $/$ stem & & Wallece, ef al. $1977 \mathrm{~b}$. \\
\hline Iron & Solution & $\mathrm{FeSO} 4$ & Cabbage & 55 & 10 & so & & Dry wgt. plent & $s$ & Hern, et el. 1976. \\
\hline Iron & Solution & & & & & 10 & LCT & Paytotaxic & & Chapmen. 1966. \\
\hline Lead & Brown carth soil & PACL2 & Wheat & 42 & 500 & 1000 & & Dry wgt. rook & 4.6 & Khan and Frantend. 1984. \\
\hline Lead & Brown earth soil & $\mathrm{PbCl2}$ & Oat & 42 & 100 & 500 & & Dry wet. rook & 5.4 & Khan and Fronithend. 1984. \\
\hline Lead & Lomy and & P6C12 & Com & $s$ & 250 & 500 & & Root length & 6.5 & Heseen, at al. 1976. \\
\hline
\end{tabular}


Table 1. (continued)

\begin{tabular}{|c|c|c|c|c|c|c|c|c|c|c|}
\hline CHEMICAL & GROWTH MEDIUM & FORM & SPECIES & DURATION & NOEC & LOEC & NOTES & GROWTH PARAMETER & pH & REFERENCE \\
\hline Lead & Lomy send & & Com & 31 & 125 & 250 & & Dry wget plene & 6 & Millet, at al. 1977 . \\
\hline Lead & Send & PSC12 & Blueatem & 84 & & 450 & LCT & Dry wgt. root/aboor & 7.8 & Miles and Perber. 1979. \\
\hline Lead & Send & $\mathrm{PBC12}$ & Blucatem & 84 & & 450 & LCT & Dry wet. rook & 4.8 & Miles end Parker. 1979. \\
\hline Lead & Sendy loom & CaCl2 & Rod oak & 112 & 20 & so & & Dry wgt. pleat & 6 & Dixon. 1988. \\
\hline Lead & Sill loom & $\mathrm{PbC12}$ & Rye & 10 & 100 & 5000 & & Dry wgt. abook & 5.9 & Carbon and Rolfe. 1979. \\
\hline Lead & Sitty eley lowm & POCL2 & Sycamone & 90 & & so & LCT & Leaf biomeses & & Carlion end Bazzaz. 1977. \\
\hline Lead & Solution & $\mathrm{Pb}(\mathrm{NO} 3)_{2}$ & Wire grass & 14 & & 10 & LCT & Rook length & & Wong end Laul. 1985. \\
\hline Lead & Solution & $\mathrm{Pb}\left(\mathrm{NO}_{3}\right) 2$ & Bermude grene & 14 & & 10 & LCT & Rook kength & & Wong end Lea. 1985. \\
\hline Lead & Solution & $\mathrm{Pb}\left(\mathrm{NO}_{3}\right) 2$ & Bermode quass & 14 & & 10 & LCT & Rook kngth & & Wong und Lau. 1985. \\
\hline Lead & Solution & $\mathrm{PsO} 4$ & Bean & 28 & 5 & 10 & & Dry wet. plene & & Hooper. 1937. \\
\hline Lead & Solution & $\mathrm{Pb}\left(\mathrm{NO}_{3}\right) 2$ & Rye grems & 14 & & 2.5 & LCT & Leht. Iongent root/sboot & & Wong and Bradsbaw. 1982. \\
\hline Lead & Solution & $\mathrm{Po}(\mathrm{NO} 3)_{2}$ & Wire grase & 14 & 10 & 20 & & Rook lengeth & & Wouge and Lau. 1985. \\
\hline Lead & Solution & PasO4 & Bean & 28 & 5 & 10 & & Dry wgt. plant & & Hooper. 1937. \\
\hline Lead & Solution & PasO4 & Bean & 28 & 5 & 10 & & Dry wgt. plene & & Hooper. 1937. \\
\hline Lead & Solution & PoSO4 & Bean & 28 & 20 & 30 & & Dry wat. plent & & Hooper. 1937. \\
\hline Lead & Solution & PasO4 & Bean & 28 & 20 & 30 & & Dry wgt. phent & & Hooper. 1937. \\
\hline Lead & Solution & Po(NO3)2 & Wire gress & 14 & & 10 & LCT & Rool kneth & & Wong and Leu. 1985. \\
\hline Lead & Solution & $\mathrm{Po}(\mathrm{NO} 3)_{2}$ & Com & 10 & 20.7 & 207 & & Freah wgt. plant & & Stiborova, at al. 1986. \\
\hline Lead & Solution & $\mathrm{Pb}(\mathrm{NO} 3)_{2}$ & Bermude grass & 14 & & 10 & LCT & Root kengeth & & Wong and Lau. 1985. \\
\hline Lead & Alfuvial soil & $\mathrm{POCl}$ & What & 161 & 1000 & 3000 & & Dry wgt. rooushook & 5.95 & Murmoto. 1990. \\
\hline Lead & Brown canth soil & $\mathrm{PBCR}$ & Redish & 42 & 100 & 500 & & Dry wgt. rook & 5.4 & Khan and Franklend. 1983. \\
\hline Leed & Brown earth soil & $\mathrm{PbO}$ & Redish & 42 & & 1000 & LCT & Dry wat. root & 5.4 & Khan and Fremklend. 1983. \\
\hline Lead & Silt loem & $\mathrm{PbC12}$ & Fescue & 10 & 1000 & 5000 & & Dry wgt. shood & 5.9 & Carlson and Rolise. 1979. \\
\hline Lead & Soil $+\operatorname{send}(1: 1)$ & PBCl2 & Spruse & 100 & so & 100 & & Dry wgt. rooushood & 3.3 & Burten, et al. 1984. \\
\hline Lithium & Loem & LiNO3 & Cotion & 21 & 25 & so & & Dry wgt. keaf/stem & & Walleoce, et al. $197 \mathrm{c}$. \\
\hline
\end{tabular}


Table 1. (continued)

\begin{tabular}{|c|c|c|c|c|c|c|c|c|c|c|}
\hline CHEMICAL & GROWTH MEDIUM & FORM & SPECIES & DURATION & NOEC & LOEC & NOTES & GROWTH PARAMETER & pH & REFERENCE \\
\hline Lithium & Loem & LiCl & Bumh beanse & 16 & 10 & 25 & & Dry wgt. beaf & & Walleoe, at al. $197 \mathrm{c}$. \\
\hline Lithivm & Lown & $\mathrm{Li2} 2 \mathrm{C}_{2} \mathrm{O}$ & Barky & 10 & & 500 & LCT & Dry wght shood & 6 & Wallecos. 1979. \\
\hline Lithium & Soil & & Orange & 180 & & 2 & & Phytotoxic & & Aldrich, a al. 1951. \\
\hline Lithium & Solution & LiNO3 & Bush beane & 24 & & 3.5 & LCT & Dry wat. ovem & & Welleco, et al. $1977 \mathrm{c}$. \\
\hline Mangancese & Loam & $\mathrm{MnSO4}$ & Bush beans & 14 & & 500 & LCT & Dry wgt. steme & & Walleoe, a al. 1977 b. \\
\hline Manguncose & Quartz and & $\mathrm{MnSO4}$ & Sintro & 76 & & 30 & LCT & Dry wat. pleme & 4.2 & Hutlon, at al. 1978. \\
\hline Mangenese & Qunrze sand & $\mathrm{MnSO4}$ & Sintro & 76 & & 30 & LCT & Dry wgt. plent & 4.2 & Hutcon, et al. 1978. \\
\hline Mangancese & Quartz sand & $\mathrm{MnSO4}$ & Sirntero & 76 & & 30 & LCT & Dry wget pleme & 4.2 & Hution, et al. 1978. \\
\hline Mangenosece & Quartz sand & $\mathrm{MnSO4}$ & Sirnero & 76 & 30 & 45 & & Dry wgt. phent & 4.2 & Hution, at al. 1978. \\
\hline Manganeace & Quartz Sand & Mnso4 & Sintero & 76 & & 30 & LCT & Dry wgt. plent & 4.2 & Hution, of al. 1978. \\
\hline Mangunose & Solution & $\mathrm{MnSO}_{4}$ & Sproos & 32 & ॥ & 44 & & Root kngth & 6 & Leneleinrich, at al. 1992. \\
\hline Manzancese & Solution & $\mathrm{MnSO4}$ & Bush beare & 16 & & 5.5 & LCT & Dry wgt. roodkeaf/stem & & Wallece, a al. 1977b. \\
\hline Menpancese & Solution & $\mathrm{MnSO4}$ & Wheat & 30 & 30 & 90 & & Dry wgl. roolsboot & 4.8 & Burter, et al. 1990 . \\
\hline Manganese & Solution & MnsO4 & Bush beane & 21 & 5.4 & 54 & & Dry wgt. roodkenf/stem & & Wallece, a al. $1977 b$. \\
\hline Mangancese & Solution & MnSO4 & Sprose & 32 & 11 & 44 & & Rel. gwth. me & 6 & Leneheinrich, et al. 1992. \\
\hline Manganese & Solution & $\mathrm{MnSO4}$ & Sprose & $n$ & & 44 & LCT & Hgt. epicotyl & 4 & Lengheinrich et al. 1992. \\
\hline Manganese & Solution & $\mathrm{MnSO4}$ & Wheat & 30 & & 30 & LCT & Dry wget. root & 4.8 & Burbe, et al. 1990. \\
\hline Manganese & Solution & MnSO4 & Wheat & 30 & & 30 & LCT & Dry wgt. roox & 4.8 & Burbe, a al. 1990 . \\
\hline Manqunese & Solution & $\mathrm{MnSO4}$ & Sprowe & $n$ & & 44 & LCT & Hzt. cpiocoyl & 4 & Lanehrinrich et al. 1992. \\
\hline Manganese & Solution & MnSO4 & Tomato & 17 & 2.75 & 5.49 & & Dry wgt. plant & 5.5 & Le Bor, ot al. 1990 . \\
\hline Mangunese & Solution & MnsO4 & Whent & 30 & & 30 & LCT & Dyy wgt. roodshoot & 4.8 & Burbe, et al. 1990. \\
\hline Mangencese & Solution & $\mathrm{MnSO4}$ & Rye grnss & 14 & & 0.75 & LCT & Lgth. longest rook & 7 & Wong and Bradeinaw. 1982. \\
\hline Mangunese & Solution & $\mathrm{MnSO4}$ & Wheal & 30 & & 30 & LCT & Dry wgh. rook & 4.8 & Burbe, et al. 1990. \\
\hline Manqunese & Solution & $\mathrm{MnSO4}$ & Bean & 21 & 2 & 20 & & Dry wgt. moolleaves & 5 & Wallece. 1979. \\
\hline Mercury & Soil & & & & & 0.3 & LCT & Phyrodoxic & & Kloke. 1979. \\
\hline
\end{tabular}


Table 1. (continued)

\begin{tabular}{|c|c|c|c|c|c|c|c|c|c|c|}
\hline CHEMICAL & GROWTH MEDIUM & FORM & SPECIES & DURATION & NOEC & LOEC & NOTES & GROWTH PARAMETER & $\mathrm{pH}$ & REFERENCE \\
\hline Mercury & Solution & $\mathrm{CH}_{3} \mathrm{H}_{8} \mathrm{Cl}$ & Spruse & 35 & & 0.02 & LCT & Chloroptyll in noodlea & 4.3 & Schlegel, et al. 1987. \\
\hline Mereury & Solution & $\mathrm{Hg}_{8} \mathrm{Cl}_{2}$ & Rye zanes & 14 & & 5 & LCT & Leth.lonesed rootshood & 7 & Wong and Bradehww. 1982. \\
\hline Mercuny & Solution & $\mathrm{Hg}_{8}$ & Spruse & 35 & & 0.02 & LCT & Chlorophyll in noodlee & 4.3 & Sctibgel, at al. 1987. \\
\hline Mercury & Solution & $\mathrm{Ch}_{3} \mathrm{H}_{8} \mathrm{Cl}$ & Spruse & 35 & & 0.002 & LCT & Trump. rate/CO2 upulese & 4.3 & Sctilegel, et al. 1987. \\
\hline Molybdeaum & Sois & & & & & 2 & LCT & Phytocoxic & & Linzon. 1978. \\
\hline Molybdemm & Solution & & & & & 0.5 & LCT & Phyrotaxic & & Chappenen. 1966. \\
\hline Molybdemum & Solution & H2MoO4 & Bean & 14 & & 5.72 & LCT & Dry wgt. leaves & 5 & Wallece. 1979. \\
\hline Molybdenum & Solution & H2MoO4 & Bush beans & 14 & & 9.6 & LCT & Dry wat. leaf & & Wallhoe, at al. $1977 \mathrm{~b}$. \\
\hline Nichel & Loem & $\mathrm{NiSO} 4$ & Com & 19 & 100 & 250 & & Dry wgt. shood & 4.2 & Walleoce, at al. 1977d. \\
\hline Nickel & Low & $\mathrm{NiSO4}$ & Bush beans & 16 & 100 & 250 & & Dry wgt. ahood & 7.5 & Walloox, at al. $197 \mathrm{~d}$. \\
\hline Nickei & Loen & $\mathrm{NiSO4}$ & Com & 19 & 100 & 250 & & Dry wgt. ahoox & 5.6 & Walleoc, et al. $1977 \mathrm{~d}$. \\
\hline Niclerl & Loom & $\mathrm{NiSO} 4$ & Com & 19 & 100 & 250 & & Dry wget. shoot & & Walleoc, ex al. 1977d. \\
\hline Nickel & Loem & $\mathrm{NiSO4}$ & Bush beane & 28 & & 100 & LCT & Dry wgt. kaves & & Wallace, at al. 1977d. \\
\hline Niciel & Loem & NisO4 & Barky & 28 & & 25 & LCT & Dry wgt. shoox & & Wallaoc, a al. 1977 . \\
\hline Nickel & Loom & $\mathrm{NiSO} 4$ & Com & 19 & 100 & 250 & & Dry wgt. sbood & 4.2 & Wallhoc, at al. $1977 \mathrm{~d}$. \\
\hline Nickel & Lown & $\mathrm{NiSO} 4$ & Bush beense & 16 & & 100 & LCT & Dry wgt. shook & 5.8 & Wallace, at al. $1977 \mathrm{~d}$. \\
\hline Nickel & Sand & $\mathrm{NiCl} 2$ & Com & 35 & 200 & 294 & & Dry wgt. plent & $s$ & Trmynor and Knezek. 1973. \\
\hline Nichel & Sandy loam & $\mathrm{NiCl2}$ & Red Oak & 112 & 20 & so & & Dry wgt. plunt & 6 & Dixon. 1988. \\
\hline Nickel & Solution & $\mathrm{NiSO} 4$ & Rye grass & 34 & & 0.13 & LCT & Lgth. longest rood & 7 & Wong and Bradshaw. 1982. \\
\hline Nickel & Solution & $\mathrm{NiSO} 4$ & Chryaenthemum & 21 & 0.06 & 0.59 & & Dry wgt. stem/kaves & & Patel, ef al. 1976. \\
\hline Nickel & Loam & $\mathrm{NiSO} 4$ & Rye grees & 28 & 90 & 180 & & Dry wgt. shoot & 4.7 & Khalid and Tinskey. 1980. \\
\hline Niclel & Solution & & Bean & 21 & & 1.17 & LCT & Dry wgt. moodkeaves & 5 & Wallece. 1979. \\
\hline РCB & Sand & Aroclor 1254 & Soybean & 26 & 10 & 100 & & Fresh wgt, sboor & 4.7 & Weber and Mroeck. 1979. \\
\hline PCB & Send & Aroclor 1254 & Sonteen & & & 1000 & LCT & Fresh wat. shooc & 4.7 & Surek and Weber. 1980. \\
\hline PCB & Send & Aroctor 1254 & Pigmood & & 40 & 100 & & Frealh wght shoodphgh. & 4.7 & Surck and Weber. 1980. \\
\hline
\end{tabular}


Table 1. (continued)

\begin{tabular}{|c|c|c|c|c|c|c|c|c|c|c|}
\hline CHEMICAL & GROWTH MEDIUM & FORM & SPECIES & DURATION & NOEC & LOEC & NOTES & GROWTH PARAMETER & $\mathrm{pH}$ & REFERENCE \\
\hline PCB & Sand & Arocior 1254 & Soytean & . & & 1000 & LCT & Freah wat. shoox & 4.7 & Strek and Weber. 1980. \\
\hline PCB & Send & Aroclor 1254 & Pigwoed & & 20 & 40 & & Froch wgt. abootph hat. & 4.7 & Surek and Weber. 1980. \\
\hline PCB & Send & Aroctor 1254 & Soytean & & & 1000 & LCT & Freah wgt. shood/p.hgt. & 4.7 & Surek and Weber. 1980. \\
\hline PCB & Send & Aroclor 1254 & Pigweod & 28 & so & 100 & & Pland height & 4 & Surck and Wober. 1982. \\
\hline PCB & Send & Aroclor 1254 & Soybeen & & & 1000 & LCT & 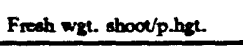 & 4.7 & Strek and Weber. 1980. \\
\hline Selenium & Loumy send & $\mathrm{Ne} 2 \mathrm{SeO} 4$ & Sorgrem & 42 & & 1 & LCT & Dry wat. abood & 5.5 & Cartbon, et all. 1991. \\
\hline Selenium & Send & $\mathrm{N} .25004$ & Sorgmese & 42 & & 1 & LCT & Dry wat. shoor & 4.9 & Carboce, et al. 1991. \\
\hline Selenium & Sand & $\mathrm{N} 22 \mathrm{SeO}$ & Soremese & 42 & & 1 & LCT & Dry wet. shoox & 6.5 & Carboen, at al. 1991. \\
\hline Selenium & Send & $\mathrm{Na2SeO}$ & Sorzenes & 42 & 1 & 2 & & Dry wat. ahood & 4.9 & Cerbocen, a al. 1991. \\
\hline Selenium & Silicas send & $\mathrm{Ne} 2 \mathrm{Se}-\mathrm{O}$ & Rye grase & 60 & 7.7 & 10.3 & & Dry wgt. plant & & Smith and Wotkinaon 1984. \\
\hline Selenivm & Silica and & $\mathrm{Ne} 2 \mathrm{SeO} 4$ & Clover & 60 & 10.3 & 12.9 & & Dry wat. plant & & Smith and Wratkineor. 1984. \\
\hline Selenium & Silice send & $\mathrm{N}=2 \mathrm{Se}=3$ & Rye zrosea & $\infty$ & 7.7 & 10.3 & & Dry wgt. plane & & Smith and Wathinson. 1984. \\
\hline Seknium & Solution & $\mathrm{Na} 2 \mathrm{Se} 03$ & What & 42 & & 1 & LCT & Dry wgt. rood/sboos;igt & & Martin 1936. \\
\hline Selenium & Solution & $\mathrm{Na} 2 \mathrm{Se} 03$ & Milk-vetch & & 9 & 27 & & Dry wat. plent & & Trekene and Trekene. 1938. \\
\hline Selenium & Solution & $\mathrm{N}_{2} 2 \mathrm{Se} \mathrm{O} 3$ & Buchenteat & 42 & & 1 & $L T$ & Dry wat. rook/aboot;ihgt & & Martin. 1936 \\
\hline Selenium & Loumy sand & $\mathrm{N}_{2} 2 \mathrm{SeO}$ & Sorgenes & 42 & & 1 & LCT & Dry ratt. shood & 6 & Curbecen, et al. 1991. \\
\hline Silver & Soil & & & & & 2 & LCT & Prynodaric & & Linzon. 1978. \\
\hline Silver & Solution & $\mathrm{A}_{2} \mathrm{NO}_{3}$ & Bean & 13 & & 0.068 & LCT & Dry wet. keaf & 5 & Wallece. 1979. \\
\hline Silver & Solution & $\mathrm{A}_{2} \mathrm{NO}_{3}$ & Bush beares & 13 & & 0.17 & LCT & Dry wel. plent & & Wallece, of al. 1977a. \\
\hline Tellurium & Solution & K2Te03 & Wheat & 42 & & 2 & LCT & Dry wrt. rook/shook & & Martin. 1937. \\
\hline Thallium & Quartz send & TiNO3 & Tobacoso & 30 & 0.1 & 0.3 & & Freach wat. shood & & Specoser. 1937. \\
\hline Thallium & Solution & & & & & 1 & LCT & Pinyodaxic & & Stikes. 1958. \\
\hline Thallium & Surface soil & & & & & 1 & & Paprotoxic & & Kloke. 1979. \\
\hline Tin & Solution & & & & & 40 & & Phytodaxic & & Schrooder. 1955. \\
\hline$T_{\mathbf{m}}$ & Surface soil & & & & & 50 & & Physoldaxic & & Kloke. 1979. \\
\hline
\end{tabular}


Table 1. (continued)

\begin{tabular}{|c|c|c|c|c|c|c|c|c|c|c|}
\hline ChEMICAL & GROWTH MEDIUM & FORM & SPECIES & DURATION & NOEC & LOEC & NOTES & GROWTH PARAMETER & $\mathrm{pH}$ & REFERENCE \\
\hline Titmium & Solution & $\mathrm{TiCl3}$ & Cabbage & 55 & 0.4 & 4 & & Dry wet. plant & 5 & Hench, a sl. 1976. \\
\hline Titennimm & Solveion & $\mathrm{TiCl3}$ & Bunh beare & 21 & & 0.069 & LCT & Dry wat kenvoes & & Walleose, of al 19772 . \\
\hline Toluene & Clay & & Soytean & 21 & 2000 & 20000 & & Froah wgt. abook & 4.75 & Overcenth, a al. 1982. \\
\hline Tolvene & Clay & & $\operatorname{cosn}$ & 21 & & 200 & LCT & Froob wgt. abood & 4.75 & Overcash, a il. 1962. \\
\hline Toluene & Sendy loem & & Corn & & 2000 & 20000 & & \% nood germination & 4 & Overcaneh, at al. 1982. \\
\hline Toluene & Sendy loam & & Com & 21 & 2000 & 20000 & & Freath wget. ahood & 5.75 & Overcenth, a al. 1982. \\
\hline Toluene & Sendy loom & & Feacue & 21 & 2000 & 20000 & & Freah wat. abood & 5.75 & Overcomen, at al. 1982. \\
\hline Tohuse & Sendy loom & & Soybonen & 21 & & 200 & LCT & Freah wat. shoot & 5.75 & Overeanh, at al. 1982. \\
\hline Toluene & Sandy loam & & Sogbean & & 200 & 2000 & & x mood yerminetion & 4 & Overcenesh, et al. 1982. \\
\hline Vanadium & Send & & Com & 67 & 1.25 & 6.25 & & Plant het./eaf area & & Sineh. 1971. \\
\hline Vanodium & Soil & & & & & 2.5 & LCT & Phytotoxic & & EPA. 1975. \\
\hline Venedium & Solution & VC13 & Cabbage & 55 & 0.4 & 4 & & Dry wgt. plant & $s$ & Hara, et at. 1976. \\
\hline Venedium & Solution & $\mathrm{NH} 4 \mathrm{VO}_{3}$ & Bush beemes & 14 & & $\lfloor .17$ & LCT & Dry wgt. rools & & Wellano, at at. 1977 . \\
\hline Vanodium & Solution & $\mathrm{NH} 4 \mathrm{VO} 3$ & Bean & 14 & & 0.22 & LCT & Dry wat. root & 5 & Wallece. 1979. \\
\hline Vanedium & Surface soil & & & & & 50 & & Phytoloxic & & Klabe. 1979. \\
\hline Zine & Alluvial soil & $\mathrm{ZnO}$ & Rixe & 105 & & 1000 & LCT & Dry wat. rook & 5.95 & Murnemoto. 1990. \\
\hline Zine & Clay loom & $\mathrm{ZasOa}$ & Compen & 31 & 157.82 & 315.94 & & Dry wat. sbood & & Gall and Barrecte. 1940 \\
\hline Zine & Cley loom & $\mathrm{ZnSOA}$ & Cons & 31 & 473.76 & 631.58 & & Dry wget. ebood & & Gall and Bamence. 1940 \\
\hline Zine & Fine andy boem & $\mathrm{ZnSO4}$ & Compen & 31 & 111.8 & 222.36 & & Dry wat. abood & & Gall and Bemette. 1940 \\
\hline Zine & Fine sandy lcom & $\mathrm{ZnSO4}$ & Con & 31 & 222.36 & 333.54 & & Dry wre. shook & & Gell and Bermetc. 1940 \\
\hline Zine & Send & $\mathrm{ZnSO4}$ & Conn & 31 & 201.83 & 403.65 & & Dry wgt. aboot & & Gell and Bemetre. $19 \times 0$ \\
\hline Zine & Sand & $\mathrm{ZnSO4}$ & Conpe & $3 t$ & 80.67 & 141.4 & & Dry wgh shook & & Gall and Barmette. 19:0 \\
\hline Zinc & Send & ZnSO4 & Cotion & $n$ & & 140 & LCT & Dry wat. ahoose & 5.5 & Loe and Page. 1967. \\
\hline Zine & Sundy looem & & Poenent & 105 & 14 & 17 & & Dry wgt. plant & & Keisling, at al. 1977. \\
\hline Zine & Sendy loom & $\mathrm{ZnSO4}$ & Sogrbean & 28 & 115 & 131 & & Dry wat, leaves & 5.5 & White, of al. 1979. \\
\hline
\end{tabular}


Table 1. (continued)

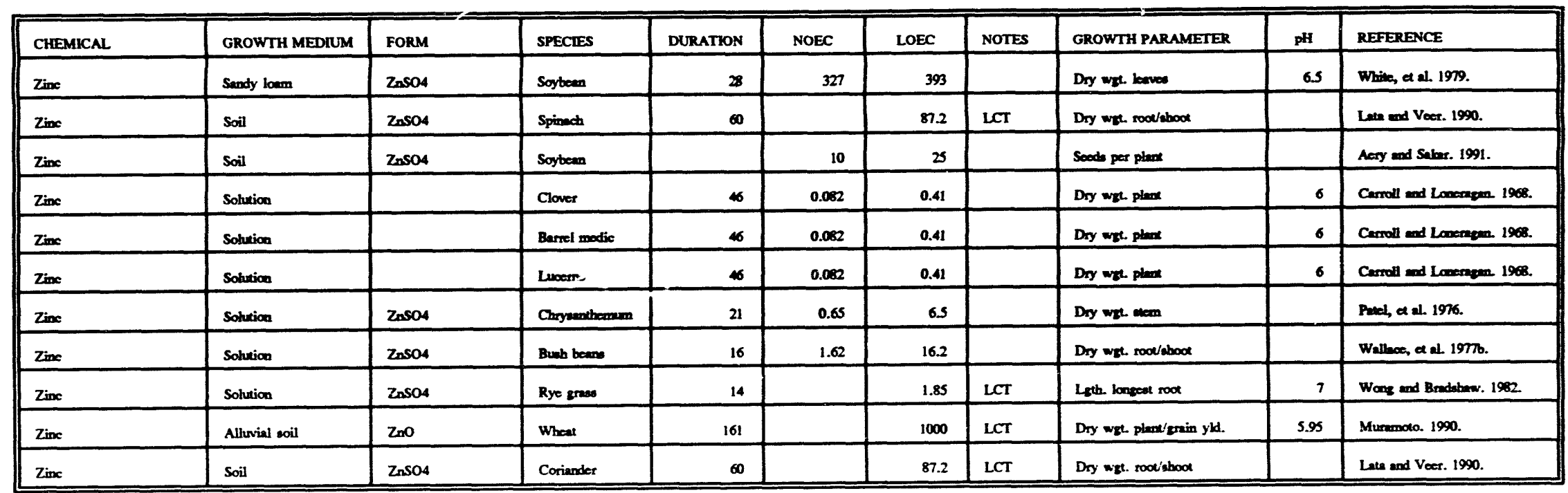


Table 2. Screening benchmark concentrations for the phytotoxicity of chemicals in soil and soil solution (Letters after concentrations denote values said in secondary sources to represent phytotoxicity thresholds)

\begin{tabular}{|c|c|c|}
\hline \multirow[t]{2}{*}{ CHEMICAL } & SOIL & SOLUTION \\
\hline & $(\mathrm{mg} / \mathrm{kg})$ & $(\mathrm{mg} / \mathrm{L})$ \\
\hline Aluminum & 10 & 0.5 \\
\hline Antimony & $5^{2}$ & - \\
\hline Arsenic & 10 & $0.02^{\mathrm{b}}$ \\
\hline Barium & 500 & $500^{\circ}$ \\
\hline Beryllium & $10^{\circ}$ & 0.5 \\
\hline Bismuth & - & $27^{b}$ \\
\hline Boron & 0.5 & $1^{\mathrm{d}}$ \\
\hline Bromine & $10^{a}$ & $15^{\mathrm{c}}$ \\
\hline Cadmium & 2 & 0.1 \\
\hline Chromium & 2 & 0.05 \\
\hline Cobalt & $25^{\circ}$ & 0.06 \\
\hline Copper & $40^{r}$ & 0.03 \\
\hline Fluorine & $200^{\circ}$ & $5^{b}$ \\
\hline Iodine & 4 & 0.5 \\
\hline Iron & -- & $10^{c}$ \\
\hline Lead & 50 & 10 \\
\hline Lithium & 2 & 3 \\
\hline Manganese & 500 & 1 \\
\hline Methyl mercury & -- & 0.002 \\
\hline Mercury & 0.3 & 0.02 \\
\hline Molybdenum & $2^{e}$ & $0.5^{\circ}$ \\
\hline Nickel & 25 & 0.1 \\
\hline Selenium & 1 & 1 \\
\hline Silver & $2^{e}$ & 0.07 \\
\hline Tellurium & - & 2 \\
\hline Thallium & $1^{*}$ & $1^{8}$ \\
\hline Tin & $50^{n}$ & $40^{h}$ \\
\hline
\end{tabular}


Table 2. (continued)

\begin{tabular}{||l|l|l||}
\hline \multirow{2}{*}{ CHEMICAL } & SOIL & SOLUTION \\
\cline { 2 - 4 } & $(\mathrm{mg} / \mathrm{kg})$ & $(\mathrm{mg} / \mathrm{L})$ \\
\hline Titanium & - & 0.07 \\
\hline Vanadium & $2.5^{1}$ & 0.2 \\
\hline Zinc & 20 & 0.4 \\
\hline 2,4 Dinitrophenol & 20 & - \\
\hline Di-n-butyl phthalate & 200 & - \\
\hline PCBs & 40 & - \\
\hline Toluene & 200 & - \\
\hline
\end{tabular}

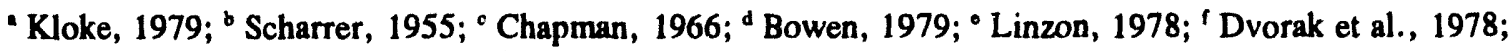

' Stiles, 1958; ' Schroeder, 1955; ' EPA, 1975. 


\section{DISTRIBUTION}

1. A. Armstrong

2. L. D. Bates

3. L. Barnthouse

4. G. Blaylock

5. R. Bonczek

6. R. Brothers

7. P. Cline

8. P. Cole

9. D. Cox

10. P. Cross

11. M. Daniel

12. K. Daniels

13. J. Dee

14. K. Eckerman

15. M. Ferre

16. J. Guty

17. C. D. Goins

18. B. Haas

19. D. Halbrook

20. P. J. Halsey

21. S. Horsewood

22. R. Hull

23. D. Jones

24. R. King

25. D. Kocher

26. R. Kramel

27. J. Kuhaida

28. B. Ladd

29. R. Mathis

30. C. W. McGinn

31. D. Mentzer

32. P.D. Miller

33. D.B. Miller

34. B. Montgomery

35. R. Moody

36. B. Nourse

78. Office of Assistant Manager for Energy Research and Development, DOE Oak Ridge Field Office, P.O. Box 2001, Oak Ridge, TN 37831-8600.

79-80. R. L. Nace, DOE, Office of Environmental Restoration, Office of Eastem Area Programs, Oak Ridge Program Division, Washington, DC 20585-0002.

81-82. R. C. Sleeman, DOE Oak Ridge Field Office, P.O. Box 2001, Oak Ridge, TN, 37831-8540.

83-84. J. T. Sweeney, DOE Oak Ridge Field Office, P.O. Box 2001, Oak Ridge, TN, 37831-8541.

85. S. P. Riddle, DOE Oak Ridge Field Office, P.O. Box 2001, Oak Ridge, TN, 37831-8541.

86. D. W. Swindle, Radian Corporation, 120 South Jefferson Circle, Oak Ridge, TN, 37830.

87-88. Office of Scientific and Technical Information, P.O. Box 62, Oak Ridge, TN, 37831.
37. D. Opresko
40. S. Pack
41. S. T. Purucker
2. S. Reith
45. B. Ross
46. G. E. Rymer
49. L. Scott
50. P.A. Schrandt
51. J. Sharp
52. W. Snedaker
55. M. Steinhauff
56. G. Stephens
Stinnette
60. A. Temeshy
61. J. Trabalka
62. J. Tremaine
T. Trenkler
65. C. Webb
66. D. Wilkes
68. F. Zafran
69. Central Research Library
70-74. ER Document Management Center
75-76. Laboratory Records Depl.
77. ORNL Patent Section 
11
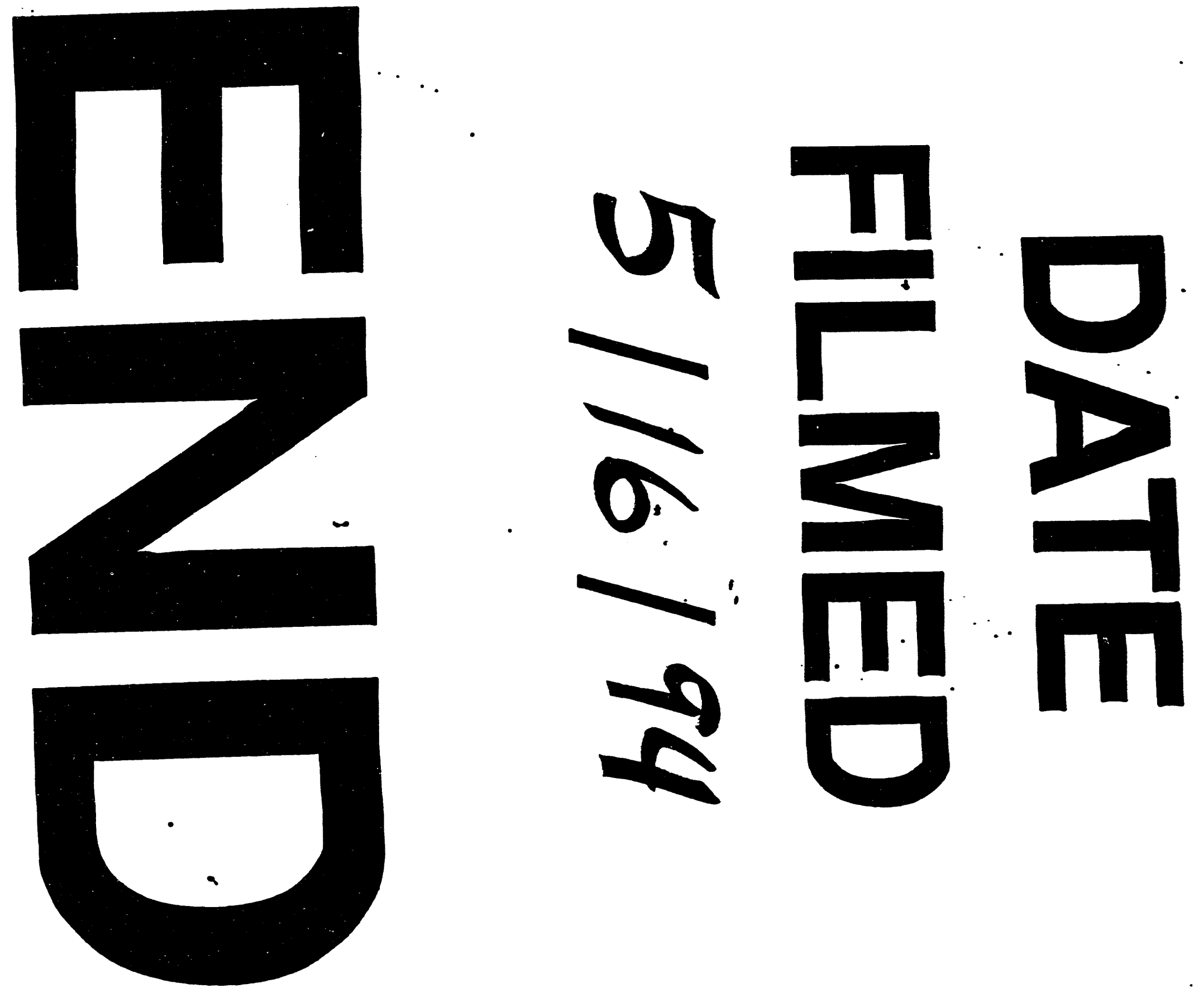


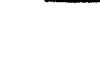
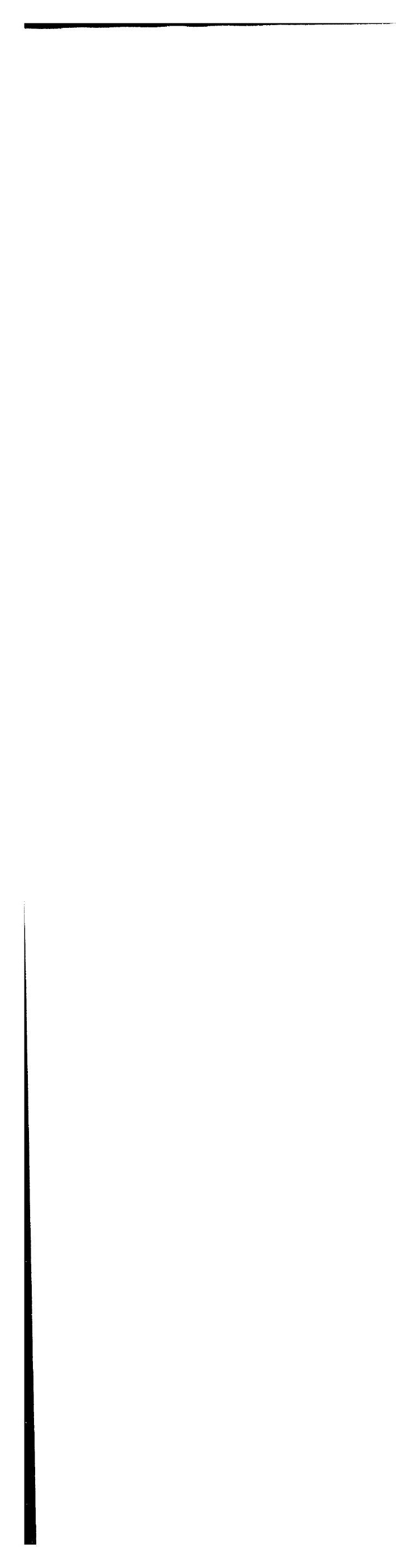